Document downloaded from:

http://hdl.handle.net/10251/84979

This paper must be cited as:

Alberdi, O.; Arriaga, H.; Calvet, S.; Estellés, F.; Merino, P. (2016). Ammonia and greenhouse gas emissions from an enriched cage laying hen facility. Biosystems Engineering. 144:1-12. doi:10.1016/j.biosystemseng.2016.01.009.

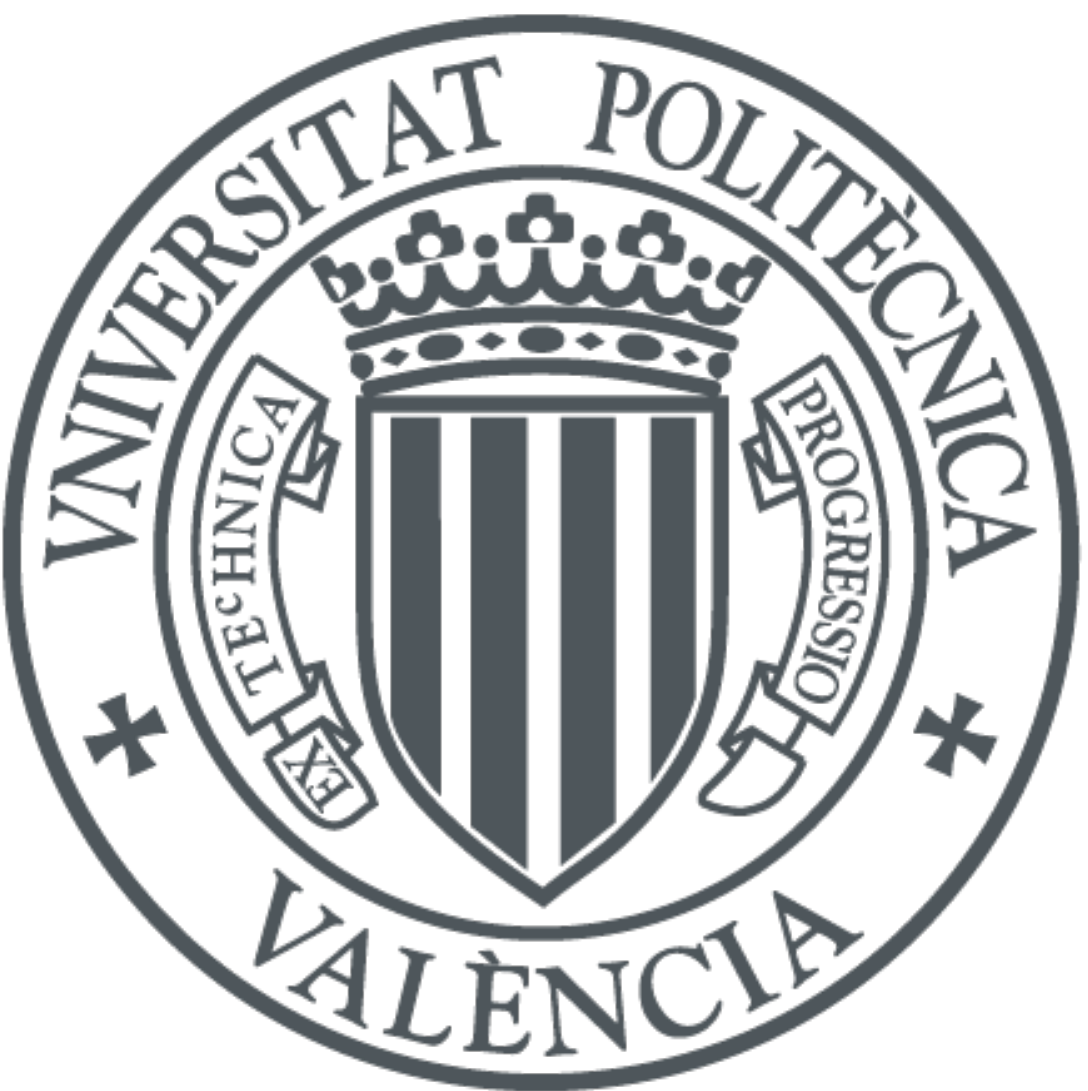

The final publication is available at

http://dx.doi.org/ 10.1016/j.biosystemseng.2016.01.009

Copyright Elsevier

Additional Information 


\section{Ammonia and greenhouse gas emissions from an enriched cage laying hen facility}

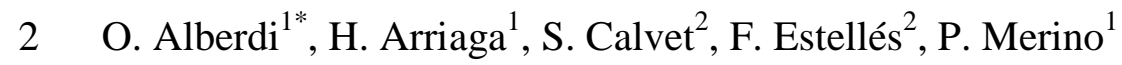

3 (1) NEIKER-Tecnalia, Environment Quality Department, Parque tecnológico de Bizkaia, parcela 812. 48160,

4 Derio (Bizkaia), SP

(2) Universitat Politécnica de Valencia, Institute of Animal Science and Technology, 46022, Valencia, SP

*Corresponding author: E-mail: oalberdi@neiker.eus

7 ABSTRACT

8 Ammonia, methane, nitrous oxide and carbon dioxide emissions were measured during a

9 complete productive cycle in an enriched cage laying hen facility under typical oceanic conditions. Continuous monitoring of gas concentration, ventilation rate and environmental

11 parameters were conducted from April 2012 to September 2013. The diurnal and seasonal

12 pattern of gas emissions was analyzed.

13 Seasonality effect was found for $\mathrm{NH}_{3}$ emission, showing an average emission of $144.9 \mathrm{mg} \mathrm{d}$

$14{ }^{1}$ hen $^{-1}$ and $90.3 \mathrm{mg} \mathrm{d}^{-1}$ hen $^{-1}$ in summer and winter respectively. An $\mathrm{NH}_{3}$ emission factor of

$157 \%$ of total $\mathrm{N}$ in manure was defined for this system. Greenhouse gases also showed a

16 diurnal pattern differing in each case. For $\mathrm{CO}_{2}$, even if averaged emission values $(80.2-$

$1795.9 \mathrm{~g} \mathrm{~d}^{-1} \mathrm{hen}^{-1}$ ) do not answer to seasonality, a distinct pattern was observed between winter

18 and summer related to ventilation rate. On the contrary, in the case of both $\mathrm{CH}_{4}$ and $\mathrm{N}_{2} \mathrm{O}$,

19 averaged values varied between winter and summer, showing the opposite diurnal pattern

20 among seasons for each gas. These results show that on-farm emission monitoring studies

21 are necessary to identify gas emission patterns and define proper farm-scale mitigation

22 measures.

23 Keywords: diurnal variation; emission factor; gas concentration; hen manure; seasonality;

24 ventilation rate. 
Livestock intensification is associated to concerns on animal welfare and environmental issues such as air pollution. The need to improve the welfare and the productivity together with the mitigation of air pollution has led either governments or producers to the adoption of several international agreements. Regarding egg production sector in EU, intensified laying hen farms had to adopt Directive 1999/74/EC on animal welfare in 2012. According to this regulation, conventional cages (CC) are prohibited across EU since then. Despite alternative production systems have been implemented at varying levels in different EU countries, most CC farms have switched into enriched cage (EC) production system. In this sense, Spain, which is the $3^{\text {rd }}$ egg producer country in EU (MAGRAMA, 2013), has currently more than $85 \%$ of its laying hen population producing through EC production system. From an environmental perspective, EU state members are obliged to reduce $\mathrm{NH}_{3}$ and GHG losses by adopting Kyoto and Gothenburg protocols together with Directive 2001/81/EC concerning national emission ceilings (NEC). In order to reduce these emissions, EU created Directive 2010/75/EU, known as Industrial Emission Directive (IED). Laying hen farms with more than 40,000 hens are obliged to comply with IED Directive by implementing best available techniques to reduce gaseous losses.

Ammonia $\left(\mathrm{NH}_{3}\right)$ is one of the main pollutant gases associated with poultry operations, which also lead to poor indoor air quality that affects on the health of animals and workers (Portejoie, Martinez, Landmann, 2002). It also has an impact on vegetation, water and atmospheric environment (Henry \& Aherne, 2014). It has been reported that $\mathrm{NH}_{3}$ concentrations and emissions in poultry houses are usually higher than those from other livestock categories, e.g., dairy cattle and swine (Groot Koerkamp et al., 1998). In this sense, Nicholson, Chambers, and Walker (2004) concluded that strategies to reduce $\mathrm{NH}_{3}$ emissions from poultry farming would be most effective if focused on housing and land 
spreading practices, where the greatest losses occur. On the contrary, methane $\left(\mathrm{CH}_{4}\right)$ and nitrous oxide $\left(\mathrm{N}_{2} \mathrm{O}\right)$ emission from these facilities are lower if compared to other livestock productions, although according to IPCC (2013) both are greenhouse gases with a higher warming potential than carbon dioxide $\left(\mathrm{CO}_{2}\right)$.

The emission of $\mathrm{NH}_{3}$ from poultry houses has been widely investigated although most of the studies on laying hen units have been carried out in Central and Northern European countries, and USA, where either the environmental conditions or production systems may differ with respect to South European countries. In contrast to $\mathrm{NH}_{3}$, fewer data on the emissions of $\mathrm{CH}_{4}$ and $\mathrm{N}_{2} \mathrm{O}$ from animal houses are available (Fournel, Pelletier, Godbout, Lagacé, Feddes, 2012a; Shepherd et al., 2015; Wathes, Holden, Sneath, White, Phillips, 1997 and Zhu, Dong, Zhou, Xin, Chen, 2011). Moreover, most of the research on air quality in laying hen houses in Europe has been conducted based on short-time measurements (Nimmermark, Lund, Gustafsson, Eduard, 2009), thus not covering seasonal variations, which have a known key effect on ventilation rates that directly affect pollutant concentrations in the barn. Long term and continuous monitoring is therefore needed to obtain deeper knowledge on gaseous emissions driving factors. This is a key element when proposing mitigation strategies that would better adapt to specific conditions.

The main objective of this paper was to report a sound baseline characterization of $\mathrm{NH}_{3}$, $\mathrm{CH}_{4}, \mathrm{CO}_{2}$ and $\mathrm{N}_{2} \mathrm{O}$ concentrations and emissions from a commercial farm of laying hens under oceanic climatic conditions, located in the Basque Country. A second objective was to analyze the effect of factors such as ventilation, temperature, feeding or manure management on gaseous losses.

\section{Material and methods}

\subsection{Animals and housing}


Approximately 52,000 Lohmann-Brown hens were housed in a commercial laying hen unit in a vertical tiered EC system adapted to Directive 1999/74/EC.

The house (Figure 1) was $17 \mathrm{~m}$ wide and $66 \mathrm{~m}$ long and enriched cages were arranged in 6 rows of 9 tier cages. The lighting period was 17:7 (light:dark) hours per day. The farm was selected to be representative of the current egg production facilities in the Basque Country in terms of management practices.

The hens were fed on a phase feeding system composed of three phases differing in crude protein content (Table 1).

Animal live weight (LW) was estimated from data provided by the supplier for a Lohmann Brown hen (Lohmann Tierzucht GMBH, 2013) according to animals' age. Bird mortality, laying rate, egg production, feed intake and feed conversion ratio was recorded on a daily basis by the producer and used to calculate bird inventory and productive parameters. Productive parameters of the laying hens during the experiment for different feeding phases are presented in Table 2.

The rate of lay reached $90 \%$ at week 23 , remaining at $90.8 \%$ during the first feeding phase, and then, it decreased gradually until the end of the cycle (78.1\%). The feed conversion ratio in contrast, did not changed throughout the cycle and follows the ratios detailed by the animal supplier.

\subsection{Environmental conditions}

Outside weather conditions of the location during the study were: average air temperature of $10.7^{\circ} \mathrm{C}$ and $20.0^{\circ} \mathrm{C}$, air relative humidity of $76.0 \%$ and $86.3 \%$ and rainfall rate of 618 and $101 \mathrm{~mm}$ (Euskalmet, 2014) for winter and summer respectively. These climate parameters are within the values recorded during the last 20 years for the Atlantic region, being representative of the oceanic conditions. 
Five temperature and relative humidity (RH) sensors (Onset, HOBO U12-013, USA, precision $\pm 0.35^{\circ} \mathrm{C}$ and $\pm 2.5 \%$, respectively) were installed at the facility. One sensor was placed outside the house, two at the air inlets and the other two close to the fans.

101 Temperature and RH were monitored and recorded every 15 min. An automated system

102 (Tecno Poultry Equipment, Macronew 3, Italy) regulated inside temperature through

103 windows opening, cooling system and the activation of 18 fans (EM50n, Munters, Sweden,

104 air flow rate $42.125 \mathrm{~m}^{3} \mathrm{~h}^{-1}$ at differential pressure $=0 \mathrm{~Pa}$ ) set up within a tunnel ventilation system (Figure 1).

106 Ventilation rate (VR) was measured under the usual rearing conditions of the farm following

107 the methodology described by Calvet, Cambra-López, Blanes-Vidal, Estellés, and Torres

108 (2010). The average percentage of operation of each fan was obtained every 5 minutes. An

109 electronic data logger system (Binary Devices S.L., Datalogger 244, Spain) converted every

110 second the electric signal from each fan into digital data on fan status. All on-line sensors

111 were downloaded every 10 days.

112 The airflow rate of each fan was individually calibrated at different static pressures. Air was

113 ducted $30 \mathrm{~cm}$ and the velocity measured by a hot wire anemometer (Testo 425, Germany,

114 accuracy $\pm 0.03 \mathrm{~m} \mathrm{~s}^{-1}$ ) at 25 locations in the section (ASHRAE, 2001). Static pressure was

115 continuously measured and recorded every $5 \mathrm{~min}$ by a pressure drop meter (Veris, PX, USA,

116 accuracy $\pm 0.5 \mathrm{~Pa}$ ). The resulting average airflow rate of fans, associated to each pressure

117 drop recorded in the building during calibration events, were used to create the

118 corresponding linear relationship (Eq.1)

$y=-0.4405 x+43.909$

$R^{2}=0.7378$

120 where, 


$$
x=\text { Pressure Drop }(\mathrm{Pa})
$$

123 Total ventilation rate for each hour was calculated by integrating the number of operating

124 fans and the individual airflow rate as given in Eq.1 for each pressure drop recorded.

\subsection{Manure characterization}

126 Manure was accumulated on belts under the cages from 2 to 4 days before being discharged.

127 The producer recorded the time of each manure removal. A representative sample of manure

128 from the belt (approximately $2 \mathrm{~kg}$ ) was collected fortnightly and analyzed for dry matter

129 (DM), total nitrogen (Ntot), ammonium nitrogen $\left(\mathrm{NH}_{4}{ }^{+}-\mathrm{N}\right)$, organic matter $(\mathrm{OM})$ and $\mathrm{pH}$.

130 The amount of manure removed from the building was weighed at the farm after each

131 manure removal.

\subsection{Gas concentrations and emissions}

133 Gas concentrations $\left(\mathrm{NH}_{3}, \mathrm{CH}_{4}, \mathrm{CO}_{2}\right.$ and $\left.\mathrm{N}_{2} \mathrm{O}\right)$ were measured continuously over 18 months

134 between April 2012 and September 2013 by using a factory calibrated INNOVA 1412

135 Photoacoustic multi gas analyzer (PAMGA) coupled with an INNOVA 1309 multipoint

136 sampler (LumaSense, Denmark). According to the technical specification of the INNOVA

137 1412, the detection limit of the measurement is $0.2 \mathrm{ppm}$ for $\mathrm{NH}_{3}, 0.4 \mathrm{ppm}$ for $\mathrm{CH}_{4}, 0.03$

138 ppm for $\mathrm{N}_{2} \mathrm{O}$ and $1.5 \mathrm{ppm}$ for $\mathrm{CO}_{2}$. A standard gas containing certified concentrations $\left(\mathrm{CO}_{2}\right.$ :

$13915,000 \mathrm{ppm}, \mathrm{CH}_{4}: 100 \mathrm{ppm}, \mathrm{N}_{2} \mathrm{O}: 25 \mathrm{ppm}$ ) was used to verify the response of PAMGA over

140 a set of automatically diluted reference concentrations. Besides, air from the barn was

141 sampled in 10L Tedlar bags and measured by gas chromatography (Agilent, 7890A,USA) -

142 and a second PAMGA (Bruel\&Kjaer, 1302, Denmark). In this sense, when concentrations

143 are confirmed with another measuring method, the uncertainty due to unexpected

144 interferences can be neglected (Hassouna, Robin, Charpiot, Edouard, Meda, 2013). 
145 Readings fell within $5 \%$ RSD, thus it was not necessary to remove the analyser for

146 recalibration.

147 Each gas sampling cycle was composed of 12 gas samples from different locations (4 at the

148 air inlet opening and 8 sampling points next to the extraction fans). Each cycle interval

149 lasted 20 minutes. The air was pumped from the sampling locations to the analyser through

150 Teflon tubing (6 mm outside diameter, and $4 \mathrm{~mm}$ inside diameter) to avoid $\mathrm{NH}_{3}$ adsorption

151 to the sampling lines. Each tube was equipped with PFT-Filters (nSpire Health Ltd.,

152 Hertford, UK) to protect from dust. Sampling lines run completely inside the building. Thus,

153 they were kept under a stable temperature, which prevented any in-line moisture

154 condensation. Besides, all the air sampling and analysing equipment (PAMGA, multipoint

155 sampler and external pump) were kept inside an air conditioned outdoor rack enclosure

156 placed in a clean room to prevent them from excessive heat, dust and moist.

157 According to Equation 2, gas emissions were calculated in an hourly basis:

158

$$
E=\left(C_{\text {outlet }}-C_{\text {inlet }}\right) \times V
$$

159

where $\mathrm{E}$ is the emission $\left(\mathrm{mg} \mathrm{h}^{-1}\right), \mathrm{C}_{\text {outlet }}$ and $\mathrm{C}_{\text {inlet }}$ is the outlet and inlet gas concentration,

160 respectively $\left(\mathrm{mg} \mathrm{m}^{-3}\right)$, and $\mathrm{V}$ is the VR in the building $\left(\mathrm{m}^{3} \mathrm{~h}^{-1}\right)$.

161 Emission was also expressed both per hen (hens present in the hen house on the

162 measurement day) in $\mathrm{mg} \mathrm{d}^{-1} \mathrm{hen}^{-1}$ or per animal mass as $\mathrm{g} \mathrm{h}^{-1} 500 \mathrm{~kg}^{-1} \mathrm{LW}$ (considering the

163 number of hens present in the building and the corresponding weight).

\subsection{Data analysis}

165 Considering the high number of gas concentration and emission data collected during the experiment, an analysis of variance led to a high significance in the parameters considered.

167 This kind of statistical analysis was not able to identify the effect of independent variables 
168

169

170

171

172

173

174

175

176

177

178 (Estellés, Calvet, Ogink, 2010):

179

180 where,

184

185

\section{6}

187

188 presented for results analysis. statistical package.

\footnotetext{
(Estellés, Calvet, Ogink, 2010):
}

$X_{h}=T+\left[A \cos \left(\frac{h 2 \pi}{24}-\frac{D 2 \pi}{24}\right)\right]$

\section{Results and discussion}

on gas emissions and concentrations. Therefore, average values and standard deviations are

The relationship among continuous variables (VR, temperature and relative humidity) and gas emissions was explored through a correlation analysis using PROC CORR of the statistical package SAS 9.3 (SAS, 2013). To analyze the effect of phase feeding in manure composition, one-way analysis of variance (PROC GLM) was performed using the same

The diurnal variation of gas emissions was explored for the 2 extreme seasons (winter and summer). Daily average emissions were calculated to this aim. Data were modelled using the PROC NLIN of SAS, following a regression equation based on the Fourier Transform

$$
\begin{aligned}
& X=\text { Variable target } \\
& T=\text { Mean value } \\
& A=\text { Amplitude } \\
& D=\text { Time at which the maximum occurred } \\
& h=\text { target time }
\end{aligned}
$$

Significant differences are expressed at $\mathrm{P}<0.05$.

\subsection{Environmental conditions and ventilation rates}


Daily average outside temperature during the measurement period ranged from $4.0^{\circ} \mathrm{C}$ to

$19027.1^{\circ} \mathrm{C}$, reflecting typical weather conditions in the region. Inside the farm, temperature

191 ranged from $18.0^{\circ} \mathrm{C}$ to $25.4^{\circ} \mathrm{C}$ with an average value of $22.4^{\circ} \mathrm{C}$. The daily mean indoor

192 temperatures showed variations corresponding to seasonal variations of outdoor

193 temperatures. Outside relative humidity presented a low variation $(77.3 \pm 11.8 \%)$ during the

194 measurement period (Table 3) due to the rainfall registered in the location along the year

195 (1240 mm), which is characteristic of oceanic climate. Despite being slightly lower than

196 those from outside, inside relative humidity remained more stable $(66.1 \pm 8.9)$ during the

197 experimental period. In some occasions, when inside temperature was higher than $25^{\circ} \mathrm{C}$,

198 also the cooling refrigeration system was activated. This system operated $18 \%$ of days, with

199 an average activation of $12 \mathrm{~h} \mathrm{~d}^{-1}$. The higher relative humidity values recorded at summer

2002012 and 2013 may be related to the activation of the cooling system.

201 Daily average VR ranged from $1.110^{6} \mathrm{~m}^{3} \mathrm{~d}^{-1}$ to $16.610^{6} \mathrm{~m}^{3} \mathrm{~d}^{-1}$. As expected, VR were 202 closely related to outdoor ambient temperatures (Figure 2), being higher in summer due to 203 higher outdoor temperatures (Table 3, Figure 3). Despite the exponential relationship 204 between temperature and VR, a saturation point would be expected for VR at higher 205 temperatures.

\subsection{Manure characteristics}

207 Manure composition and production are presented in Table 4. The mean DM content of 208 manure was $27.2 \%$, which was slightly lower than values reported for manure belt systems 209 by previous studies (Fabbri, Valli, Guarino, Costa, Mazzotta, 2007; Fournel et al., 2012a).

210 Nonetheless, the observed DM content was within the range reported by EC (2003) for 211 manure belt systems without manure drying tubes (25\%-35\%). No seasonality effects were 212 observed on manure DM content during the experimental period $(\mathrm{P}>0.05)$. The lack of a 213 seasonality effect was attributed to the high RH values observed throughout the year (Table 
3). As mentioned above, RH higher than $70 \%$ was typical for the humid oceanic weather

215 conditions. Despite the higher VR measured in summer, the high RH of the incoming air

216 would not have favoured water evaporation from manure as Kroodsma, Arkenbout, and

217 Stoffers (1985) stated. In addition, the activation of the cooling system during the hottest

218 days increased the air RH by $7 \%$ in comparison to summer RH values without cooling

219 activation.

220 Total nitrogen content in the manure $(5.3 \pm 0.8 \%)$ was influenced by the feeding phase. A

221 significant decrease $(\mathrm{P}<0.05)$ on manure Ntot content was observed during the second and

222 third phases compared to the first one (Table 4). Fournel et al. (2012a) and Fabbri et al.

223 (2007) reported higher $\mathrm{N}$ content in the manure (6.5 and 7.1\% of DM) in manure belt system

224 than the values obtained in this study. On the contrary of Ntot, no relationship among

225 feeding phase and $\mathrm{NH}_{4}{ }^{+}-\mathrm{N}$ content was observed.

226 The average value for manure $\mathrm{pH}$ was $7.6( \pm 0.5)$, which was in the range of the values 227 reported by other authors. Fournel et al. (2012a) observed values of 6.7 while Fabbri et al. 228 (2007) and Chepete, Xin, and Li (2011) recorded pH values of 8.3 and 8.6, respectively. A $229 \mathrm{pH}$ below 7 would have kept ammonia bound as $\mathrm{NH}_{4}{ }^{+}-\mathrm{N}$, reducing $\mathrm{NH}_{3}$ volatilization. Uric 230 acid represents around $70 \%$ of the Ntot in poultry faeces. The $\mathrm{pH}$ recorded in this study, 231 could have favoured around $60 \%$ uric acid degradation as described by Groot Koerkamp 232 (1994).

\subsection{Gas Concentrations and Emissions}

\subsubsection{Ammonia}

235 Average inside $\mathrm{NH}_{3}$ concentration measured in this study was $2.0 \mathrm{mg} \mathrm{m}^{-3}( \pm 1.4)$, which was 236 within the range reported by Zhao, Shepherd, Li, and Xin (2015) for a similar EC facility.

237 On the other hand, $\mathrm{Ni}$ et al. (2012) recorded higher mean $\mathrm{NH}_{3}$ concentration $\left(9 \mathrm{mg} \mathrm{m}^{-3}\right)$ in a 238 CC facility with manure belt system. This difference was attributed to factors such as VR, 
flock density and manure management. Ventilation rate reported by Ni et al. was half of VR

240 observed in the current study. Stocking rates reported by Ni et al. were 1.6 times higher

$241\left(13.8 \mathrm{~kg} \mathrm{LW} \mathrm{m}^{-3}\right)$. Finally, despite manure removal frequency was similar between both

242 studies, Ni et al. did not totally remove manure from the belts.

243 The maximum $\mathrm{NH}_{3}$ concentration in the building was found during the first month of the

244 flock (April 2012), which could be related to the combination of the low VR (Figure 3E) and 245 the early laying stage period. Maximum $\mathrm{NH}_{3}$ in our study was $12.1 \mathrm{mg} \mathrm{m}^{-3}$, which is lower 246 than the threshold of $17.4 \mathrm{mg} \mathrm{m}^{-3}$ as aversive to laying hens reported in previous studies 247 (Kristensen, Burgess, Demmers, Wathes, 2000). Variations in seasonal $\mathrm{NH}_{3}$ concentrations 248 were closely related to differences in outdoor temperatures and VR. Thus, at higher outdoor 249 temperatures and VR, reduced $\mathrm{NH}_{3}$ concentrations in the exhaust air were recorded (Table $2503)$.

251 Average $\mathrm{NH}_{3}$ emission in this study was $115.7 \pm 85.6 \mathrm{mg} \mathrm{d}^{-1} \mathrm{hen}^{-1}$ (Table 3). Our results were 252 slightly higher than those cited in EC (2003) for EC system with belt manure, being $95.9 \mathrm{mg}$ $253 \mathrm{~d}^{-1}$ hen $^{-1}$. Other authors, such as Liang et al. (2005) and Fournel, Pelletier, Godbout, Lagacé, 254 and Feddes (2012b), reported $94 \mathrm{mg} \mathrm{d}^{-1} \mathrm{hen}^{-1}$ and $87 \mathrm{mg} \mathrm{d}^{-1} \mathrm{hen}^{-1}$, respectively, for cage 255 systems with belt manure removal system. This difference could be attributed to hen 256 commercial strains, as when we referred emissions to $500 \mathrm{~kg} \mathrm{LW}$, values were similar, with $2571.21 \mathrm{~g} \mathrm{~h}^{-1} 500 \mathrm{~kg}^{-1} \mathrm{LW}$ reported by Fournel et al. and $1.22 \mathrm{~g} \mathrm{~h}^{-1} 500 \mathrm{~kg}^{-1} \mathrm{LW}$ for our study. 258 We attributed this difference to the commercial strain which weighed $1.5 \mathrm{~kg} \mathrm{LW} \mathrm{hen}^{-1}$ in the 259 case of Fournel et al. as VR (4.0 and $\left.4.2 \mathrm{~m}^{3} \mathrm{~h}^{-1} \mathrm{hen}^{-1}\right)$, manure removal frequency and $\mathrm{pH}$ 260 were similar. Likewise, our results were consistent with those reported by Liang et al. (2005) 261 with $1.28 \mathrm{~g} \mathrm{~h}^{-1} 500 \mathrm{~kg}^{-1} \mathrm{LW}$. In this case, $\mathrm{pH}$ of the manure (7.4) and manure removal 262 frequency (3-4 days) were similar among both studies. 
263 However, emission rates may also range from $54.0 \mathrm{mg} \mathrm{d}^{-1} \mathrm{hen}^{-1}$ to $169.9 \mathrm{mg} \mathrm{d}^{-1} \mathrm{hen}^{-1}$ as

264 Shepherd et al. (2015) and Fabbri et al. (2007) reported. These variations were mainly

265 attributed to different VR of each experiment, which were $2.2 \mathrm{~m}^{3} \mathrm{hen}^{-1} \mathrm{~h}^{-1}$ and $6.2 \mathrm{~m}^{3} \mathrm{hen}^{-1}$

$266 \mathrm{~h}^{-1}$, respectively. In this sense, $\mathrm{NH}_{3}$ emission did not differ between our study and data

267 reported by Fabbri et al. (2007) at similar VR in summer 2012 (Table 3). It is well known

268 the influence of air velocity over the manure surface promoting $\mathrm{NH}_{3}$ volatilization (Groot

269 Koerkamp, 1994). Besides ventilation, other factors such as $\mathrm{pH}$ and manure DM content

270 affecting $\mathrm{NH}_{3}$ emissions (Elliot \& Collins, 1982; Groot Koerkamp, 1994) were also more

271 favourable in that study $(\mathrm{pH}=8.3$ and 37\% DM, Fabbri et al., 2007).

272 The highest $\mathrm{NH}_{3}$ emissions $\left(11.9 \pm 3.3 \mathrm{mg} \mathrm{h}^{-1} \mathrm{hen}^{-1}\right.$ ) happened in summer conditions (weeks 27328 and 83, Figure 3A). Several factors could explain these peak emissions, such as a 5-day 274 manure accumulation inside the building in week 28 and a higher inside temperature $\left(25^{\circ} \mathrm{C}\right)$ 275 and VR with 6.0 and $9.8 \mathrm{~m}^{3} \mathrm{~h}^{-1} \mathrm{hen}^{-1}$ in weeks 28 and 83 respectively. Other $\mathrm{NH}_{3}$ emission 276 peaks found in summer (weeks $34,35,39$ ) or early autumn (week 44) could also be 277 attributed to high temperature, ventilation and manure accumulation time inside the 278 building. On the contrary, low emissions were found from end November 2012 to beginning 279 of May 2013 (Figure 3A). During this period, average outside temperature was below $10^{\circ} \mathrm{C}$, 280 which together with a low VR and an average of 3 day manure accumulation time could 281 have contributed to lower emissions. Data collected during week 25 and week 28 suggested 282 a potential effect of manure extraction frequency. For similar temperature, ventilation and 283 RH conditions, lower emissions were registered in week 25 with a daily removal, whereas 284 highest emissions occurred after 5 day accumulation period in week 28 . The effect of 285 manure removal frequency should therefore be further explored (Figure 3A).

286 Seasonal differences in $\mathrm{NH}_{3}$ emission were observed in this study, in consistency with other 287 authors (Da Borso \& Chimenti, 1999; Nicholson et al., 2004). Mean $\mathrm{NH}_{3}$ emission reached 
90.3 $\mathrm{mg} \mathrm{d}^{-1} \mathrm{hen}^{-1}$ in winter 2013, $165.4 \mathrm{mg} \mathrm{d}^{-1} \mathrm{hen}^{-1}$ in summer 2012 and $136.3 \mathrm{mg} \mathrm{d}^{-1} \mathrm{hen}^{-1}$

289 in summer 2013, similar results to those obtained by Da Borso and Chiumenti in summer in 290 a similar production system in the north of Italy, with $134 \mathrm{mg} \mathrm{d}^{-1} \mathrm{hen}^{-1}$. However, they 291 obtained lower values in winter $\left(27 \mathrm{mg} \mathrm{d}^{-1} \mathrm{hen}^{-1}\right)$, possibly due to lower temperatures in the 292 area. This is the case of Nimmermark et al. (2009), who reported low $\mathrm{NH}_{3}$ emissions in 293 winter $\left(75 \mathrm{mg} \mathrm{d}^{-1} \mathrm{hen}^{-1}\right)$ due to the low temperatures registered in Sweden $\left(-6.1^{\circ} \mathrm{C}\right)$, even 294 with a 5-day manure removal frequency. In this sense, Groot Koerkamp, Keen, Van 295 Niekerk, and Smit, (1995) found that less than 5\% of uric acid is degraded under $15^{\circ} \mathrm{C}$. 296 Nicholson et al. (2004) also reported higher $\mathrm{NH}_{3}$ emission rates in summer than in winter 297 (mean $3.2 \mathrm{gh}^{-1} 500 \mathrm{~kg}^{-1} \mathrm{LW}$ and $1.4 \mathrm{~g} \mathrm{~h}^{-1} 500 \mathrm{~kg}^{-1} \mathrm{LW}$ respectively), in response to the 298 different VR in summer $\left(8.9 \mathrm{~m}^{3} \mathrm{~s}^{-1}\right)$ and winter $\left(1.4 \mathrm{~m}^{3} \mathrm{~s}^{-1}\right)$. Shepherd et al. (2015) also found 299 higher emission rates with ambient temperatures above $20^{\circ} \mathrm{C}$ and greater velocities in the 300 barn. This seasonal pattern was also observed by Wathes et al. (1997), who reported an $\mathrm{NH}_{3}$ 301 emission rate of $192 \mathrm{~g} \mathrm{~d}^{-1} \mathrm{AU}^{-1}$ in winter and $290 \mathrm{~g} \mathrm{~d}^{-1} \mathrm{AU}^{-1}$ in summer from four deep-pit 302 layer houses in England ( $\mathrm{AU}=454 \mathrm{~kg} \mathrm{LW}$ equivalent $).$

303 Deep-pit houses, generally show higher emissions than cage systems, with values of 1,065 $304 \mathrm{mg} \mathrm{d}^{-1}$ hen $^{-1}$ (Fournel et al., 2012b), $870 \mathrm{mg} \mathrm{d}^{-1}$ hen $^{-1}$ (Da Borso \& Chiumenti, 1999) and $305446 \mathrm{mg} \mathrm{d}^{-1}$ hen $^{-1}$ (Fabbri et al., 2007). The manure management in these installations, 306 together with their building design, ventilation and temperature ranges would explain this 307 variability. In aviary systems, emissions can be three times higher than in cage systems 308 (Groot Koerkamp et al., 1995) and vary from 353 to $463 \mathrm{mg} \mathrm{d}^{-1} \mathrm{hen}^{-1}$ (Dekker, Aarnink, de 309 Boer, Groot Koerkamp, 2011), which suggests that a modification in the manure management system could reduce $\mathrm{NH}_{3}$ emissions. Nevertheless, the highest $\mathrm{NH}_{3}$ emissions 311 were derived from floor production systems, with 2,100 $\mathrm{mg} \mathrm{d}^{-1} \mathrm{hen}^{-1}$ (Nimmermark et al., 312 2009) and free range housing systems, with $1,342 \mathrm{mg} \mathrm{d}^{-1} \mathrm{hen}^{-1}$ (Dobeic \& Pintarič, 2011). 
Apart from housing characteristics, other factors such as feeding and manure management

314 affect $\mathrm{NH}_{3}$ emissions. During the period of study, feed crude protein ranged from 16.0 to

$31516.7 \%$, resulting significantly different $(\mathrm{P}<0.05)$ Ntot content of manure (Table 2$)$.

316 Nevertheless this effect was not clearly observed on $\mathrm{NH}_{3}$ emission, probably due to the

317 existence of several interacting factors that explain in house $\mathrm{NH}_{3}$ concentrations and

318 emissions. In relation to manure management, both $\mathrm{NH}_{3}$ concentration and emission showed

319 short-lived peaks in an interval of 2-4 days, in coincidence with belt cleaning frequency. It

320 has been previously described that belt cleaning operations lead to a decrease on $\mathrm{NH}_{3}$

321 emissions (Dekker et al., 2011; Liang et al., 2005).

322 The parameters discussed in this paper related to density of hen population, housing type,

323 ventilation regime and manure management had a significant impact on emissions. Thus,

324 results from this study gave sound information to produce $\mathrm{NH}_{3}$ emission factor (EF) for

325 laying hen installations with belt cleaning systems. Ammonia EF for laying hen facilities are

326 currently established by EMEP-Corinair guidebook (2013) based on excreted $\mathrm{NH}_{4}{ }^{+}-\mathrm{N}$ and

327 uric acid. This guidebook considers that $41 \%$ of TAN is volatilized as $\mathrm{NH}_{3}$, which would be

328 equivalent to $29 \%$ of Ntot. Our results showed that $7 \%$ of Ntot was lost as $\mathrm{NH}_{3}$ in EC

329 system, in which manure was on average removed every 3 days. Ammonia EF given by

330 EMEP-Corinair is based on a slurry whose TAN content accounts for $70 \%$ of Ntot. This

331 guidebook assumes that all uric acid becomes $\mathrm{NH}_{4}{ }^{+}-\mathrm{N}$. However, mean TAN content in our

332 research represented about $30 \%$ of Ntot. This result suggests that not all the uric acid is

333 converted into $\mathrm{NH}_{4}{ }^{+}-\mathrm{N}$ in belt system with frequent manure removals.

\subsubsection{Methane}

335 Average $\mathrm{CH}_{4}$ concentration was $3.4 \mathrm{mg} \mathrm{m}^{-3}( \pm 1.9)$. Methane concentration followed the 336 similar pattern as $\mathrm{CH}_{4}$ emissions, mainly from week 18 to 40 and 73 to 93 showing the 337 opposite pattern to $\mathrm{CO}_{2}$ (Figure 3B, 3D). Average $\mathrm{CH}_{4}$ emission in this study was $90 \mathrm{mg} \mathrm{d}^{-1}$ 
$338 \mathrm{hen}^{-1}$. No clear effect of season was observed, similarly to Zhu et al. (2011). Nevertheless,

$339 \mathrm{CH}_{4}$ emissions increased in summer, when the highest water content in air was recorded.

340 Thus, these data should be taken with caution as the combination of high air water content

341 and $\mathrm{CH}_{4}$ concentration lower to $20 \mathrm{ppm}$ has been found to lead to $\mathrm{CH}_{4}$ overestimation by

342 PAMGA (Cortus, Jacobson, Hetchler, Heber, Bogan, 2015). Methane emission referred to

343 animal mass $\left(0.96 \mathrm{~g} \mathrm{~h}^{-1} 500 \mathrm{~kg}^{-1} \mathrm{LW}\right)$ was in the same range than values reported by Fournel

344 et al. (2012a), who found an average emission rate of $0.95 \mathrm{~g} \mathrm{~h}^{-1} 500 \mathrm{~kg}^{-1} \mathrm{LW}$. Fabbri et al.

345 (2007) reported higher values $\left(2.14 \mathrm{~g} \mathrm{~h}^{-1} 500 \mathrm{~kg}^{-1} \mathrm{LW}\right)$.

346 The presence of manure on the belt did not affect emissions of $\mathrm{CH}_{4}$ as described by Dekker

347 et al. (2011) for aviary systems, where bedding exists as a mixture of faeces and bedding

348 material. Theoretically, in this study, the absence of bedding, together with the frequent

349 removal of manure would have favoured lower $\mathrm{CH}_{4}$ emissions in comparison to aviary

350 systems. However, Dekker et al. reported higher and lower $\mathrm{CH}_{4}$ emission from three

351 different types of aviary systems (1.70, 0.37, $\left.0.64 \mathrm{~g} \mathrm{~h}^{-1} 500 \mathrm{~kg}^{-1} \mathrm{LW}\right)$.

\subsubsection{Nitrous oxide}

353 Low concentrations were registered for $\mathrm{N}_{2} \mathrm{O}$, similarly to results reported by other authors

354 for a variety of laying hen production systems (Fabbri et al., 2007; Jungbluth, Hartung,

355 Brose, 2001). Further, denitrification is of minor importance in hen manure as it contains

356 few nitrate or nitrite. Inside $\mathrm{N}_{2} \mathrm{O}$ concentrations were not always higher than outside

357 concentrations, resulting, on some occasions, in negative emissions.

358 Average $\mathrm{N}_{2} \mathrm{O}$ emission was $4.5 \mathrm{mg} \mathrm{d}^{-1}$ hen $^{-1}$ (Table 3) in our study, in the range of values

359 registered by Fournel et al. (2012a) for cage systems, with $7.1 \mathrm{mg} \mathrm{d}^{-1} \mathrm{hen}^{-1}$. The emission

360 pattern of $\mathrm{N}_{2} \mathrm{O}$ was similar to that of $\mathrm{NH}_{3}$. In contrast, the $\mathrm{N}_{2} \mathrm{O}$ emission rate was affected

361 negatively by VR $(\mathrm{P}<0.001)$ as reported Dobeic and Pintarič $(2011)$. This effect could be the

362 reason that explains the lowest emission in summer $(\mathrm{P}<0.05)$. 
364 Average indoor concentration was $1,984 \mathrm{mg} \mathrm{m}^{-3} \pm 588$. Carbon dioxide concentration was

365 indicative of the barn VR, with lower $\mathrm{CO}_{2}$ concentration corresponding to higher VR

366 (Figure 3D). This relationship was also observed by Nimmermark et al. (2009) and Zhao et

367 al. (2015), who found higher $\mathrm{CO}_{2}$ concentrations with values up to $4,497 \mathrm{mg} \mathrm{m}^{-3}$ and 3,985

$368 \mathrm{mg} \mathrm{m}^{-3}$, respectively, along with very low ventilation $\left(0.9\right.$ and $\left.2.2 \mathrm{~m}^{3} \mathrm{~h}^{-1} \mathrm{hen}^{-1}\right)$. Dekker et al.

369 (2011) reported an average $\mathrm{CO}_{2}$ concentration of $2,734 \mathrm{mg} \mathrm{m}^{-3}$ for aviary system, probably

370 due to the lower VR and the contribution of manure from bedding.

371 The VR might also partly explain the seasonal $\mathrm{CO}_{2}$ concentration pattern. In fact, the mean

$372 \mathrm{CO}_{2}$ concentration in winter was $2,511 \mathrm{mg} \mathrm{m}^{-3}$. Lower outside temperatures and VR led to

373 higher daily mean $\mathrm{CO}_{2}$ concentration (Table 3).

374 Carbon dioxide in poultry houses is originated by hen exhalation and manure release, which

375 in on site studies can not be partitioned. Both effects must be taken into account when

376 estimating the VR with $\mathrm{CO}_{2}$ balance method (Liang et al., 2005; Pedersen, Blanes-Vidal,

377 Joergensen, Chwalibog, Haeussermann, 2008). Pedersen et al. estimated that $8.3 \%$ of $\mathrm{CO}_{2}$

378 emissions measured in a laying hens house comes from manure. Also, Ni, Heber, Hanni,

379 Lim, and Diehl (2011) suggested that manure is a significant source of $\mathrm{CO}_{2}$ release in

380 commercial layer barns. In our study it was observed a slight significant increase in $\mathrm{CO}_{2}$

381 emission during the days between manure removals, is suggested due to manure

382 accumulation.

\subsection{Gas emission diurnal patterns}

384 A clear diurnal variation pattern was found for gas emissions, temperature, relative humidity

385 and VR. These variations were expressed in hourly average terms for summer and winter 
separately (Figure 4). Regression parameters obtained for measured parameters were presented in Table 5. All models were statistically significant at least at $\mathrm{p}<0.001$ (Table 5). Relative humidity in bird houses is inversely related to temperature (Seedorf et al., 1998). Ventilation rate followed the same pattern as outdoor temperature, showing a higher difference between day and night in summer, with peak values between 12 and $17 \mathrm{~h}$ (Figure $4 \mathrm{~J})$. It was observed that maximum VR in winter were similar to the lowest VR in summer, with $3.1 \mathrm{~m}^{3} \mathrm{~h}^{-1}$ hen $^{-1}$ and $3.2 \mathrm{~m}^{3} \mathrm{~h}^{-1} \mathrm{hen}^{-1}$, respectively. Gas emission patterns differed among gases under the same ventilation regime for each season, suggesting other factors could be affecting emission processes.

In the case of $\mathrm{CO}_{2}$, apart from the previously described effect of VR on those emissions, bird respiration affected $\mathrm{CO}_{2}$ diurnal emission pattern (Figure 4C). Thus, the activation of light and consequent activity of laying hens caused a sudden increase at morning and quick drop at night (Figure 4C). In this sense, Von Wachenfelt, Pedersen, and Gustafsson, (2001) observed a large diurnal variation in $\mathrm{CO}_{2}$ production, closely correlated with layer hen activity. Carbon dioxide emission pattern showed a higher difference between day and night in winter than in summer (Table 5), suggesting that low VR found in winter during night $\left(1.3 \mathrm{~m}^{3} \mathrm{~h}^{-1} \mathrm{hen}^{-1}\right)$ allowed for $\mathrm{CO}_{2}$ accumulation in the building. This fact was not observed in summer, when $\mathrm{CO}_{2}$ emissions were quite similar between day and night, not being affected by the twofold increase in VR in summer.

The opposite effect between season and diurnal emission patterns was found for $\mathrm{NH}_{3}$, when the lowest $\mathrm{NH}_{3}$ emission rate in summer was similar to the highest emission in winter, with $0.24 \mathrm{~g} \mathrm{~h}^{-1}$ and $0.26 \mathrm{~g} \mathrm{~h}^{-1}$ (Figure 4A). That is, $\mathrm{NH}_{3}$ emissions were higher in response to VR in summer, but maintained the same difference between day and night as in winter. When tested how VR affected $\mathrm{NH}_{3}$ emissions on an hourly basis, weak relationship was obtained, suggesting that the effect of ventilation was masked by other factors. There is little 
411 information on diurnal emission patterns in the literature for laying hen installations

412 (Estellés, Calvet, Ogink, 2010). Other authors (Calvet, Cambra-López, Blanes-Vidal,

413 Estellés, Torres, 2011) have also found opposite behaviours for $\mathrm{CO}_{2}$ and $\mathrm{NH}_{3}$ in broiler

414 systems.

415 Methane emission values were similar in winter and summer around $15 \mathrm{~h}$, decreasing

416 steeply in winter after this time, while emissions persisted in summer. It was observed a

417 higher difference between day and night in winter than in summer, indicating, like in the

418 case of $\mathrm{CO}_{2}$, that the low ventilation recorded in winter during night induced a certain

419 accumulation of $\mathrm{CH}_{4}$ that was emitted when ventilation reaches around $2 \mathrm{mg} \mathrm{m}^{-3}$.

420 Although low $\mathrm{N}_{2} \mathrm{O}$ emissions are reported in the literature from cage systems, it was

421 observed that emissions tended to be higher in winter than in summer. Nevertheless, as

422 found in the other gases considered, the response along the day was higher in winter than in

423 summer, supporting the hypothesis that a minimum VR was always used to avoid

424 accumulation of gases in the building. The characteristics of this experiment, carried out in

425 commercial running operations, made it difficult to establish strong relationships due to the

426 confluence of different factors such as climatic conditions and management operations

427 which were beyond the experimental control.

\section{Conclusion}

429 Gaseous concentrations and emissions were monitored in a laying hen facility during a 430 complete laying cycle in relation to manure composition, management and environmental 431 parameters. Ammonia EF was $7 \%$ of total $\mathrm{N}$ in manure in $\mathrm{EC}$ facility with belt cleaning 432 system. Seasonal and diurnal variation was observed in $\mathrm{NH}_{3}$ emissions, linked to VR and 433 manure management. 
434 Greenhouse gas emissions showed a diurnal pattern differing in each case. For $\mathrm{CO}_{2}$, even if 435 averaged emission values did not answer to seasonality, a distinct pattern was observed 436 between winter and summer related to VR. On the contrary, in the case of both $\mathrm{CH}_{4}$ and $437 \mathrm{~N}_{2} \mathrm{O}$, averaged values varied between winter and summer, showing the opposite pattern. 438 Nitrous oxide emissions were low throughout the study, making it difficult to detect 439 differences in diurnal pattern between winter and summer. On-farm emission monitoring 440 studies are necessary to identify gas emission patterns and define proper farm-scale 441 mitigation measures.

\section{Acknowledgments}

443 This work has been funded by BATFARM Interreg-Atlantic Area Project (2009-1/071)

444 entitled "Evaluation of best available techniques to decrease air and water pollution in 445 animal farms". Oier Alberdi holds a grant from the Ph.D. student's research program of the 446 Department of Economic Development and Competitiveness of the Basque Government. 447 The authors are especially grateful to Larrabe Oilotegia S.A.T. that facilitated productive 448 data and access to the farm and to the engineering company Ingeniería Avícola S.L. for the 449 detailed information on ventilation aspects of the installation.

\section{REFERENCES}

451 ASHRAE (2001). ASHRAE Fundamentals Handbook e Printed edition. Atlanta, Georgia: 452 American Society of Heating, Refrigerating and Air-Conditioning Engineers Inc.

453 Calvet, S., Cambra-López, M., Blanes-Vidal, V., Estellés, F., \& Torres, A.G. (2010). 454 Ventilation rates in mechanically-ventilated commercial poultry buildings in Southern 455 Europe: Measurement system development and uncertainty analysis. Biosystems $456 \quad$ Engineering, 106, 423-432. 
Calvet, S., Cambra-López, M., Blanes-Vidal, V., Estellés, F., \& Torres, A.G. (2011). Characterization of gas emissions from a Mediterranean broiler farm. Poultry Science, 90, 534-542.

Chepete, J.H., Xin, H., \& Li, H. (2011). Ammonia emission of laying-hen manure as affected by accumulation time. Japan Poultry Science 48, 133-138.

Cortus, E.L., Jacobson, L.D., Hetchler, B.P., Heber, A.J., Bogan, B.W. (2015). Methane and nitrous oxide analyzer comparison and emissions from dairy freestall barns with manure flushing and scraping. Atmospheric Environment, 100, 57-65.

Da Borso, F., \& Chiumenti, R. (1999). Poultry housing and manure management systems: recent development in Italy as regards ammonia emissions. Proceedings of the 8th International Conference of the FAO ESCORENA Network on Recycling of Agricultural, Municipal and Industrial Residues in Agriculture, RAMIRAN 98, Vol. 2, Posters Presentation, pp 15-21.

Dekker, S.E.M., Aarnink, A.J.A., de Boer, I.J.M., \& Groot Koerkamp, P.W.G. (2011). Emissions of ammonia, nitrous oxide, and methane from aviaries with organic laying hen husbandry. Biosystems Engineering, 110, 123-133.

Dobeic, M., \& Pintarič, Š. (2011). Laying hen and pig livestock contribution to aerial pollution in Slovenia. Acta Veterinaria (Beograd), 61, 283-293. doi:10.2298/AVB1103283D.

EC. (1999). Directive 1999/74/EC of the Council of the European Union of 19 July 1999 laying down minimum standards for the protection of laying hens. Official Journal of the European Communities, L203, 53-57.

EC. (2001). Directive 2001/81/EC of the European Parliament and of the Council of 23 October 2001 on national emission ceilings for certain atmospheric pollutants. Official Journal of the European Communities, L309, 22-30. 
EC. (2003). Reference document on best available techniques for intensive rearing of poultry and pigs (ILF-BREF).

Elliot, H.A., \& Collins, N.E. (1982). Factors affecting ammonia release in broiler houses. Transactions of the ASAE, 25, 413-424.

EMEP-Corinair (2013). Emission Inventory Guidebook 2013. Retrieved from http://www.eea.europa.eu/publications/emep-eea-guidebook-2013/.

Estellés, F., Calvet, S., \& Ogink, N. (2010). Effects of diurnal emission patterns and sampling frequency on precision of measurement methods for daily ammonia emission from animal houses. Biosystems Engineering, 107, 16-24.

EU. (2010). Directive 2010/75/EU of the European Parliament and of the Council of the European Union of 24 November 2010 on industrial emissions (integrated pollution prevention and control). Official Journal of the European Union. L334, 17-119.

Euskalmet (2014). Meteorological stations: readings collected in 2012 and 2013. Basque meteorology agency. Retrieved from http://opendata.euskadi.eus/catalogo//estaciones-meteorologicas-lecturas-recogidas-en-2012/ and http://opendata.euskadi.eus/catalogo/-/estaciones-meteorologicas-lecturas-recogidasen-2013/.

Fabbri, C., Valli, L., Guarino, M., Costa, A., \& Mazzotta, V. (2007). Ammonia, methane, nitrous oxide and particulate matter emissions from two different buildings for laying hens. Biosystems Engineering, 97, 441-455.

Fournel, S., Pelletier, F., Godbout, S., Lagacé , R., \& Feddes, J.J.R. (2012a). Greenhouse gas emission from three cage layer housing systems. Animals, 2, 1-15. 
Fournel, S., Pelletier, F., Godbout, S., Lagacé, R., \& Feddes, J.J.R. (2012b). Odour emissions, hedonic tones and ammonia emissions from three cage layer housing systems. Biosystems Engineering, 112, 181-191.

Groot Koerkamp, P.W.G. (1994). Review on emissions of ammonia from housing systems for laying hens in relation to sources, processes, building design and manure handling. Journal of Agricultural Engineering, 59, 73-87.

Groot Koerkamp, P.W.G., Keen, A., Van Niekerk, T.H.G.C., \& Smit, S. (1995). The effect of manure and litter handling and indoor climatic conditions on ammonia emissions from a battery cage and an aviary housing system for laying hens. Netherlands Journal of Agricultural Sciences, 43, 351-373.

Groot Koerkamp, P.W.G., Metz, J.H.M., Uenk, G.H., Phillips, V.R., Holder, M.R., Sneath, R.W., Short, J.L., White, R.P., Hartung, J., Seedorf, J., Schroder, M., Linkert, K.H., Pedersen, S., Takai, H., Johnsen, J.O., \& Wathes, C.M. (1998). Concentrations and emissions of ammonia in livestock buildings in northern Europe. Journal of Agricultural Engineering Research, 70(10), 79-95.

Hassouna, M., Robin, P., Charpiot, A., Edouard, N., Meda, B. (2013). Infrared photoacoustic spectroscopy in animal houses: Effect of non-compensated interferences on ammonia, nitrous oxide and methane air concentrations. Biosystems Engineering, $114,318-326$.

Henry, J., \& Aherne, J. (2014). Nitrogen deposition and exceedance of critical loads for nutrient nitrogen in Irish grasslands. Science of the Total Environment, 470-471, 216223. 
IPCC (2013). Climate Change 2013: The Physical Science Basis. Contribution of Working Group I to the Fifth Assessment Report of the Intergovernmental Panel on Climate Change. Cambridge University Press, Cambridge, UK and New York, NY, USA.

Jungbluth, T., E. Hartung, E., \& Brose, G. (2001). Greenhouse Gas Emissions from Animal Houses and Manure Stores. Nutrient Cycling in Agroecosystems, 60, 133-145.

Kristensen, H.H., Burgess, L.R., Demmers, T.G.H., \& Wathes, C.M. (2000). The preferences of laying hens for different concentrations of atmospheric ammonia. Applied Animal Behaviour Science, 68, 307-318.

Kroodsma, W., Arkenbout, J., \& Stoffers, J.A. (1985). New systems for drying poultry manure in belt batteries. Research report / Institute of agricultural engineering. I.M.A.G. no. 85-1 (Wageningen), 27 pp.

Liang, Y., Xin, H., Wheeler, E.F., Gates, R.S., Li, H., Zajaczkowski, J.S., Topper, P.A., Casey, K.D., Behrends, B.R., Burnham J.D., \& Zajaczkowski, F.J. (2005). Ammonia emissions from U.S. laying hen houses in Iowa and Pennsylvania. Transactions of the ASAE 48 (5), 1927-1941.

Lohmann Tierzucht GMBH (2013). Online management guide "Lohmann Brown-Classic". Retrieved from http://www.ltz.de/de-wAssets/docs/management-guides/en/ltzmanagement-guide-brown-classic-en2013.pdf.

Ni, J.Q., Heber, A.J., Hanni, S.M., Lim, T.T., \& Diehl, C.A. (2011). Characteristics of ammonia and carbon dioxide releases from layer hen manure. British Poultry Science 51, 326-334.

Ni, J.Q., Chai, L., Chen, L., Bogan, B.W., Wang, K., Cortus, E.L., Heber, A.J., Lim, T.T., \& Diehl, C.A. (2012). Characteristics of ammonia, hydrogen sulfide, carbon dioxide and 
particulate matter concentrations in high-rise and manure-belt. Atmospheric Environment 57, 165-174.

551 Nicholson, F.A., Chambers, B.J., \& Walker, A.W. (2004). Ammonia emissions from broiler litter and laying hen manure management systems. Biosystems Engineering, 89 (2), $175-185$.

Nimmermark, S., Lund, V., Gustafsson, G., \& Eduard, W. (2009). Ammonia, dust and bacteria in welfare-oriented systems for laying hens. Annals of Agricultural and Environmental Medicine 16, 103-113.

Portejoie, S., Martinez, J., \& Landmann, G. (2002). Ammonia of farm origin: impact on human and animal health and on the natural habitat. Productions Animales, 15, 151160.

Pedersen, S., Blanes-Vidal, V., Joergensen, H., Chwalibog, A., \& Haeussermann, A. (2008). Carbon dioxide production in animal houses: A literature review. Agricultural Engineering International: CIGR Ejournal. Muniscript BC 08 008, Vol. X. December, 2008.

SAS (2013). User's Guide: Statistics (Release 9.3). SAS® Institute Inc. Cary, NC, USA.

Seedorf, J., Hartung, J., Schroder, M., Linkert, K. H., Pedersen, S., Takai, H., Johnsen, J. O., Metz, J. H. M., Groot Koerkamp, P. W. G., Uenk, G. H., Phillips, V. R., Holden, M. R., Sneath, R. W., Short, J. L., White, R. P., \& Wathes, C. M. (1998). A survey of ventilation rates in livestock buildings in Northern Europe. Journal of Agricultural Engineering Research, 70, 39-47.

Shepherd, T.A., Zhao, Y., Li, H., Stinn, J.P., Hayes, M.D., \& Xin, H. (2015). Environmental assessment of three egg production systems - Part II. Ammonia, greenhouse gas, and particulate matter emissions. Poultry Science, 94, 534-543. 
573 Von Wachenfelt, E., Pedersen, S., \& Gustafsson, G. (2001). Release of heat, moisture and carbon dioxide in an aviary system for laying hens. British Poultry Science, 42, 171179.

576 Wathes, C.M., Holden, M.R., Sneath, R.W., White, R.P., \& Phillips, V.R. (1997).

577 Concentrations and emission rates of aerial ammonia, nitrous oxide, methane, carbon

578 dioxide, dust, and endotoxin in UK broiler and layer houses. British Poultry Science,

$579 \quad 38(1), 14-28$.

580 Zhao, Y., Shepherd, T.A., Li, H., \& Xin, H. (2015).Environmental assessment of three egg 581 production systems - Part I: Monitoring system and indoor air quality. Poultry Science, $58294,518-533$

583 Zhu, Z., Dong, H., Zhou, Z., Xin, H., \& Chen, Y. (2011). Ammonia and greenhouse gases 584 concentrations and emissions of a naturally ventilated laying hen house in Northeast 585 China. Agricultural and Biological Engineers, 54 (3), 1085-1091. 


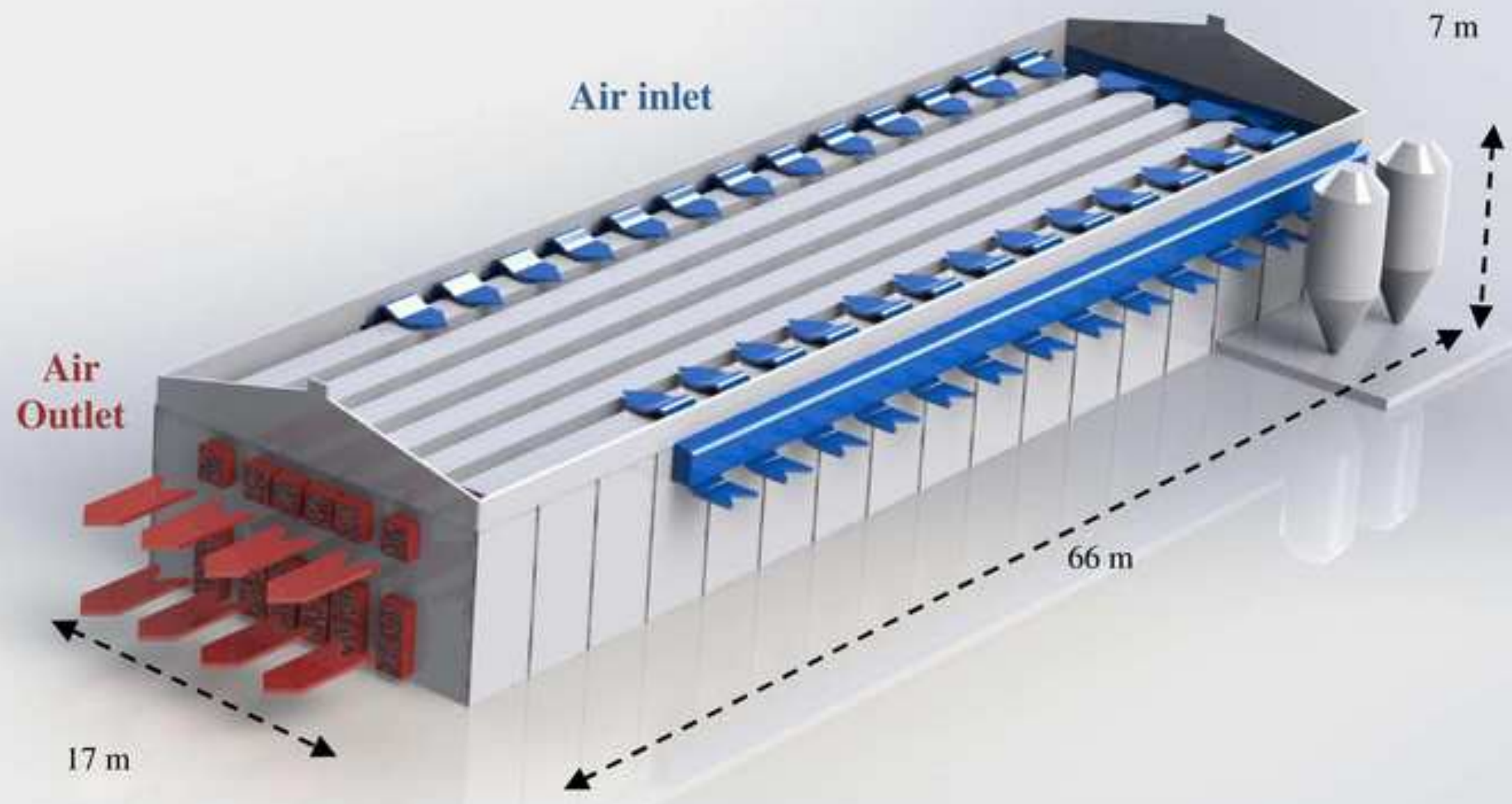




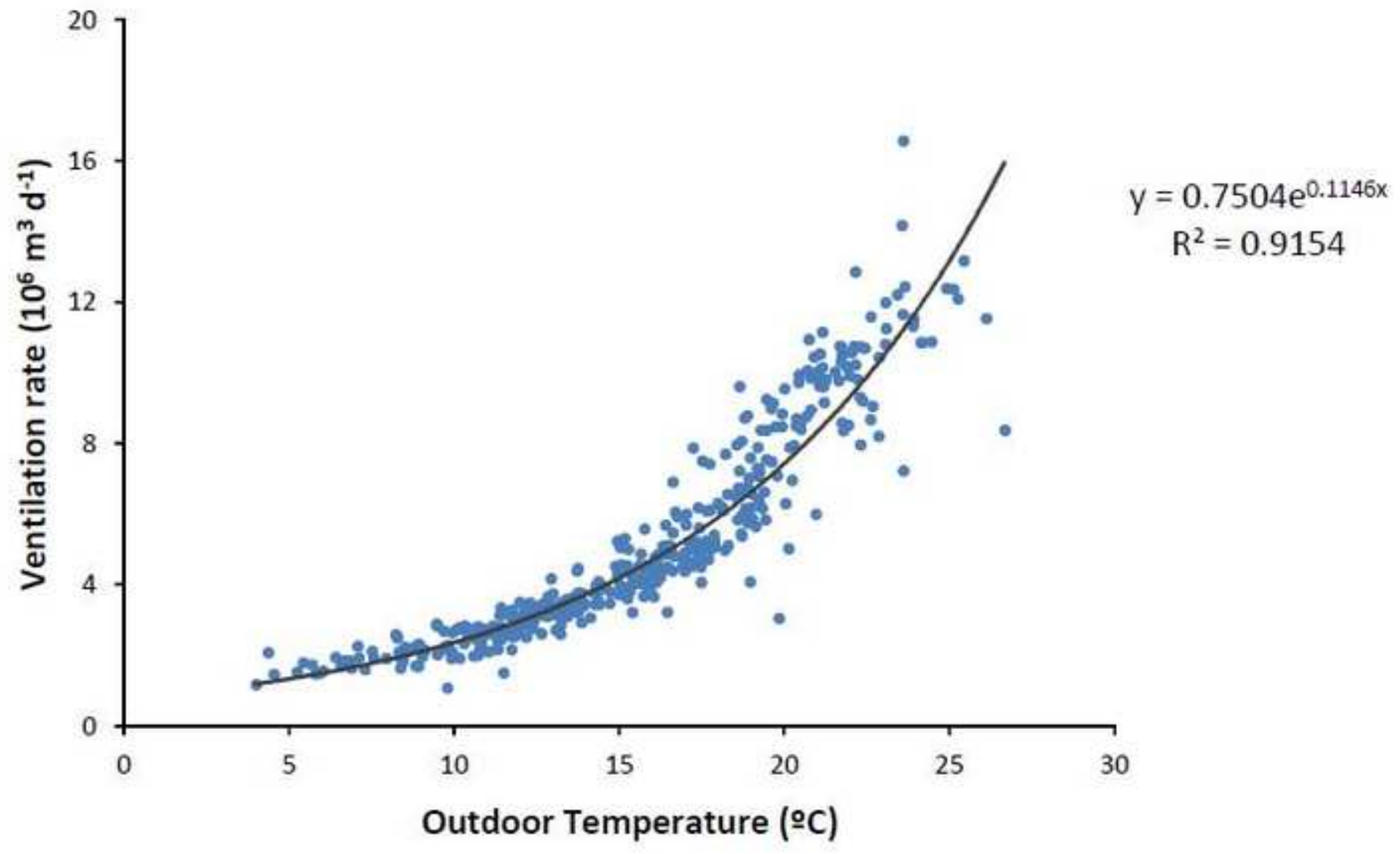


A. $-\mathrm{NH}_{3}$

B. $-\mathrm{CH}_{4}$
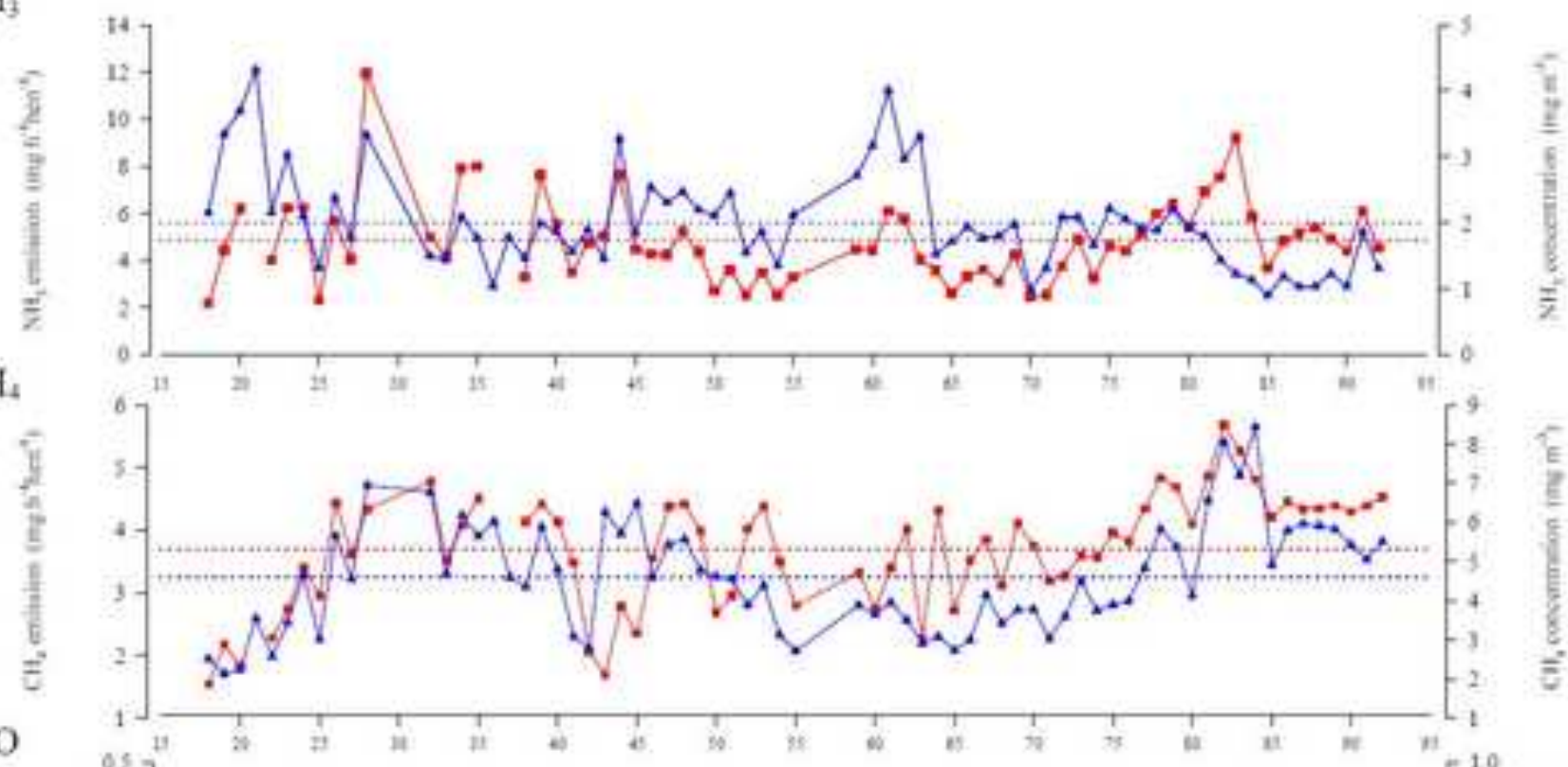

D. $-\mathrm{CO}_{2}$

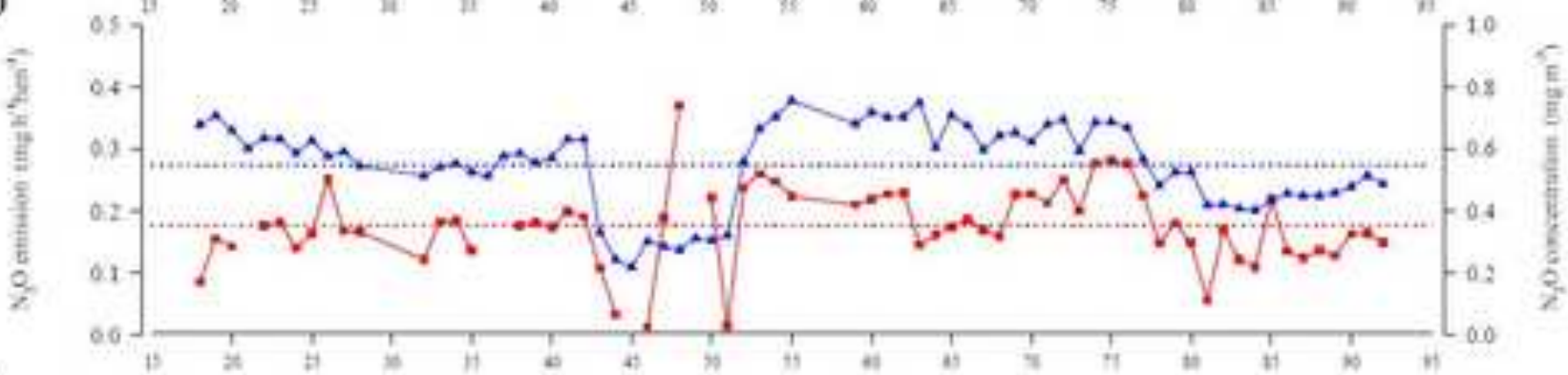

E.-VR

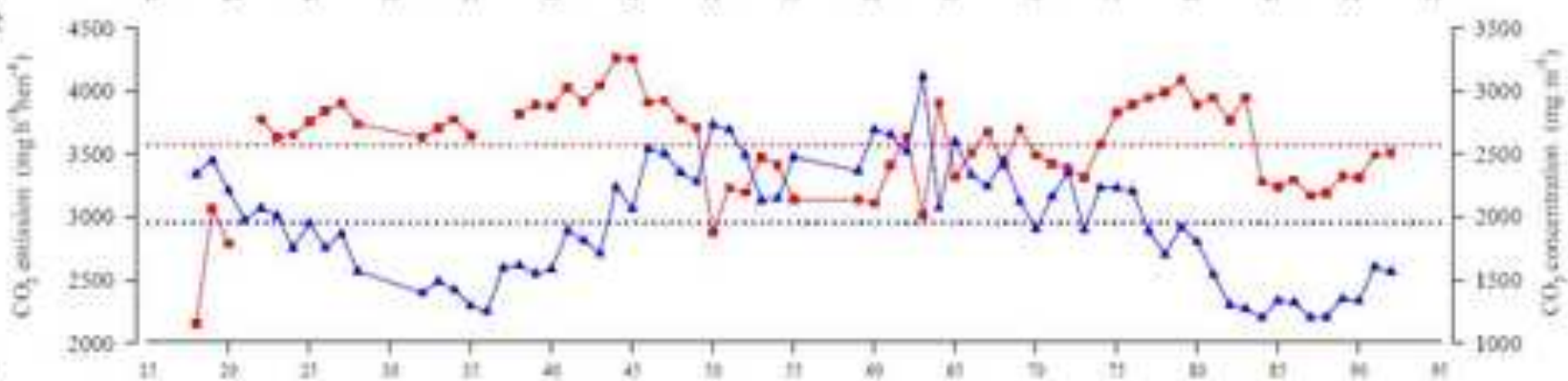

F.-I
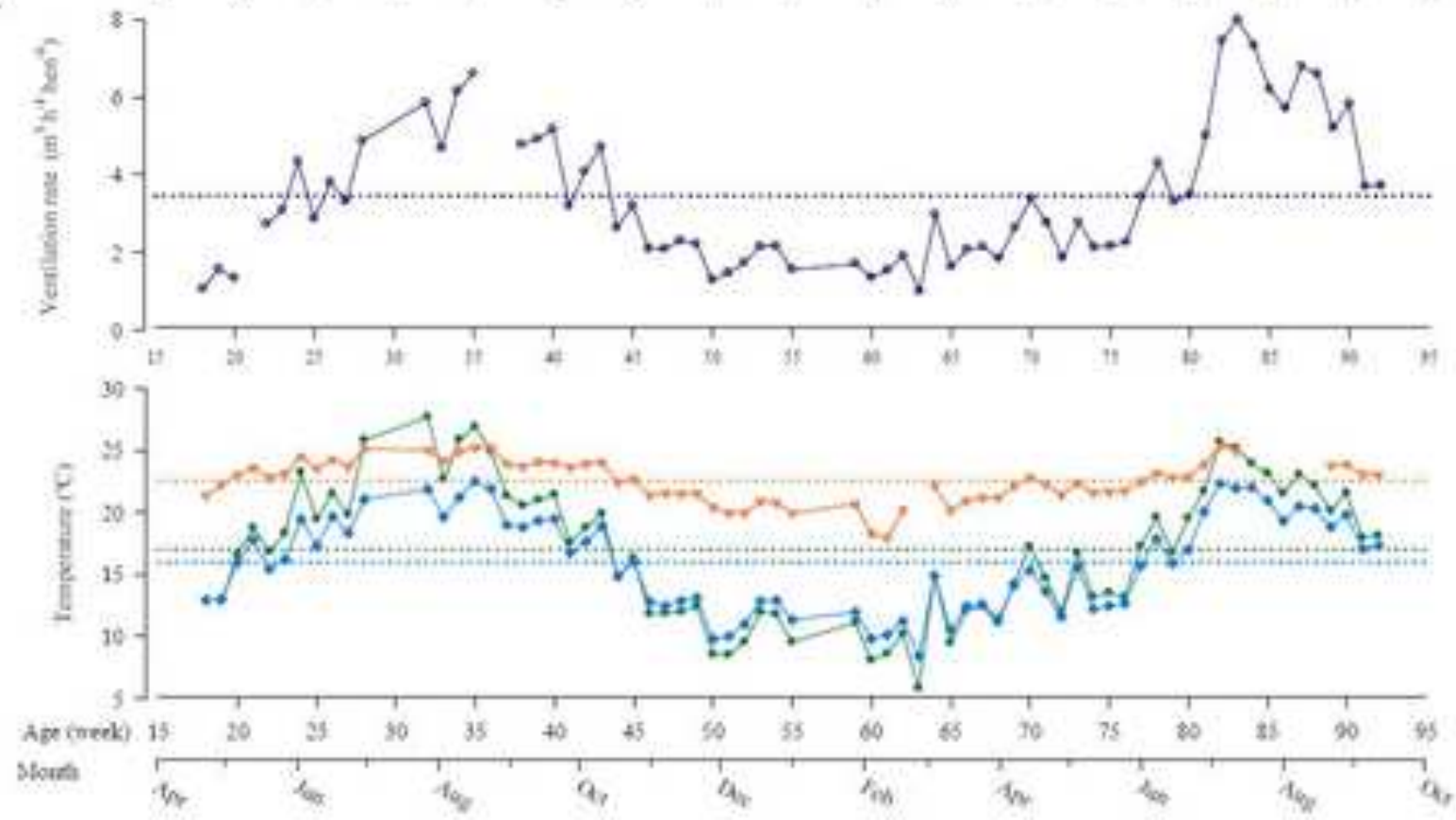

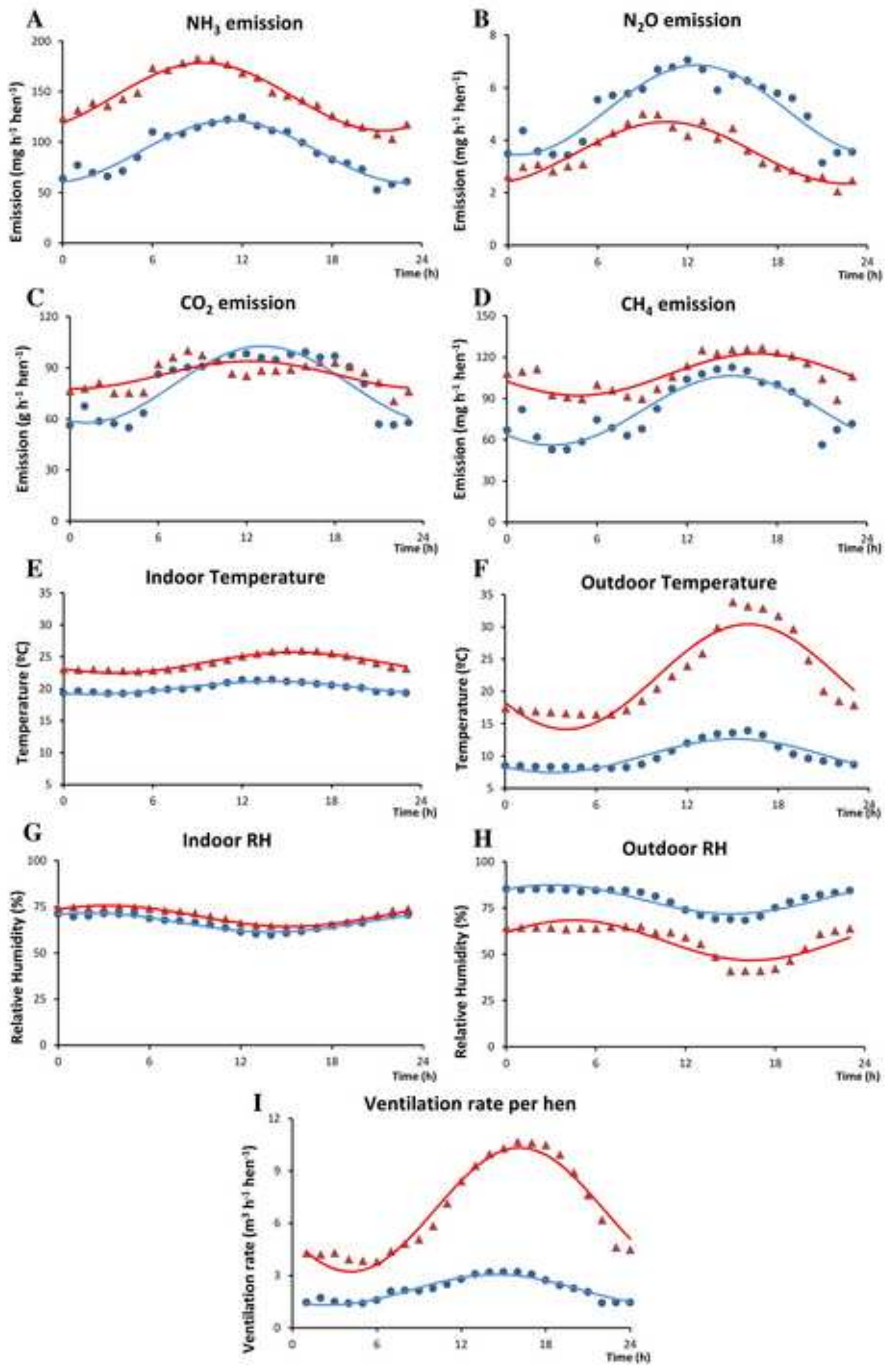


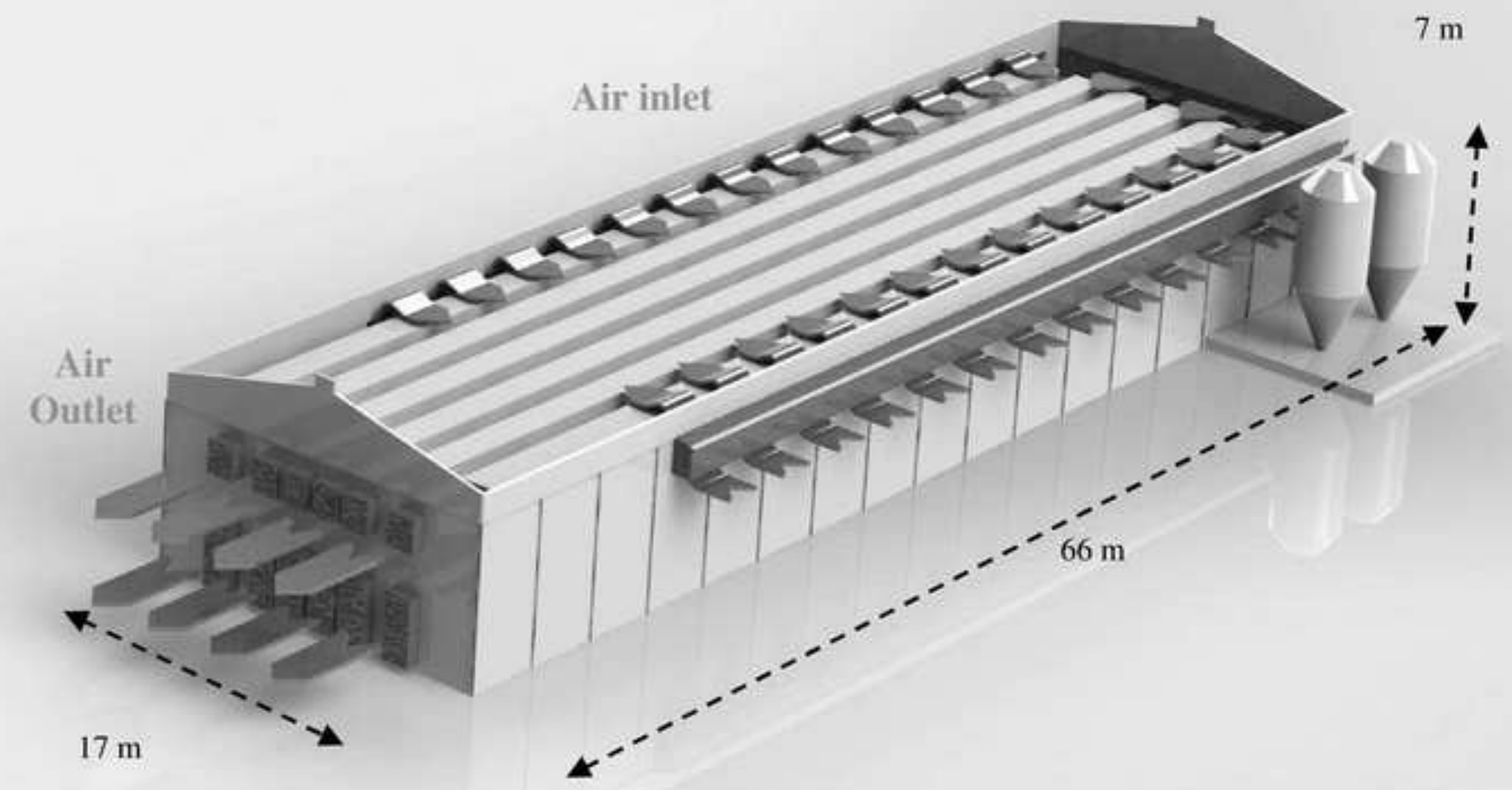




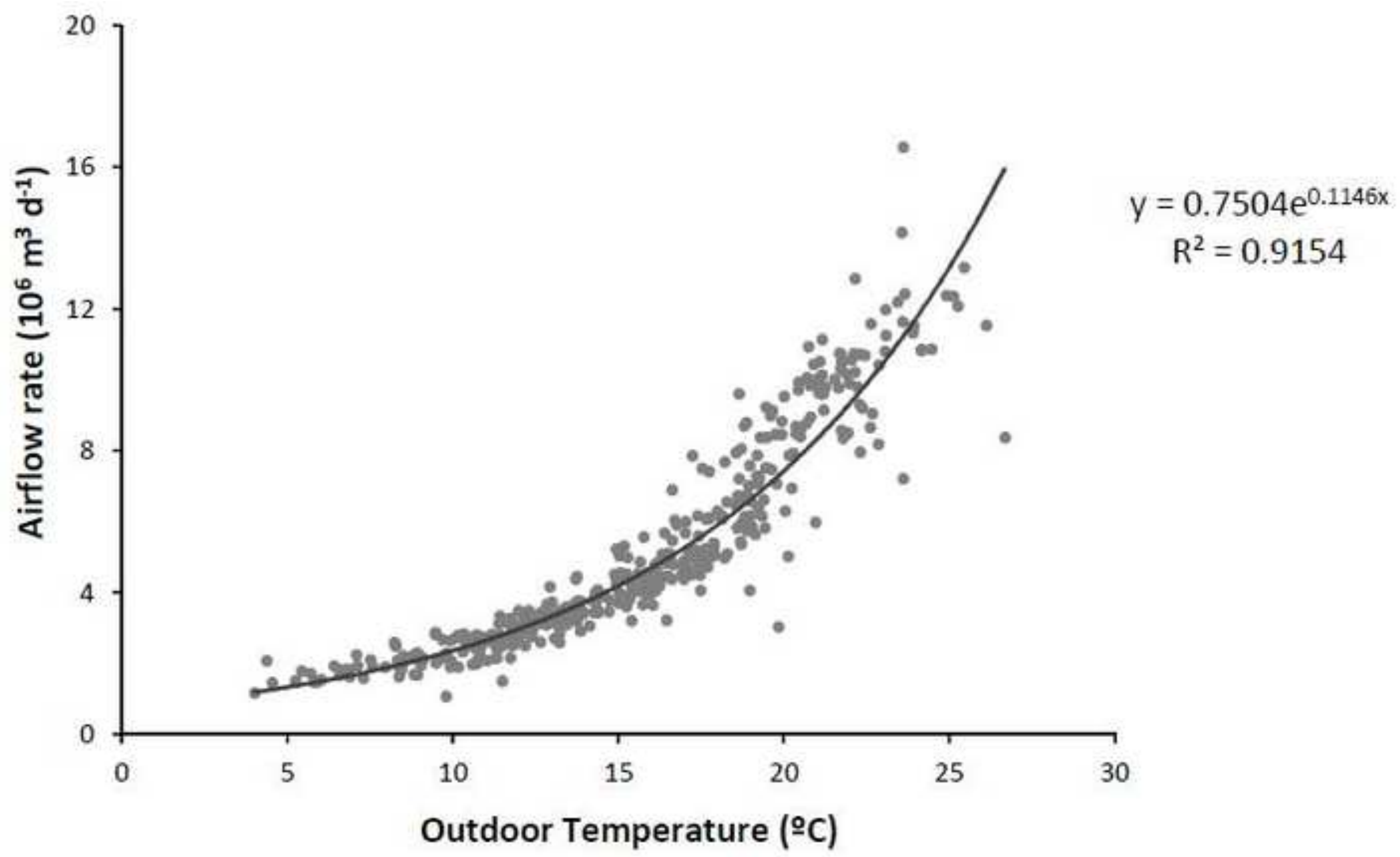




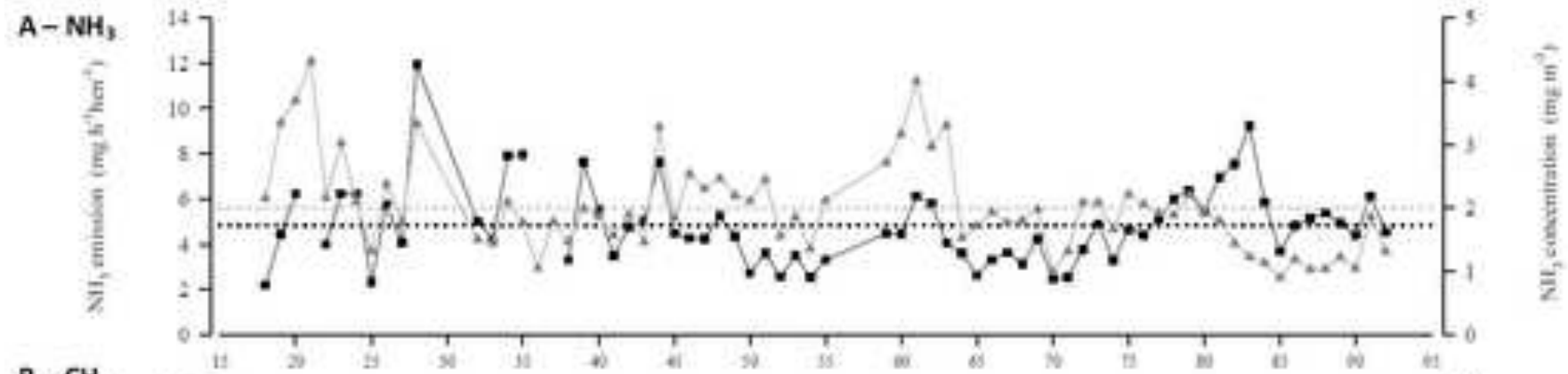

$\mathrm{B}-\mathrm{CH}_{4}$
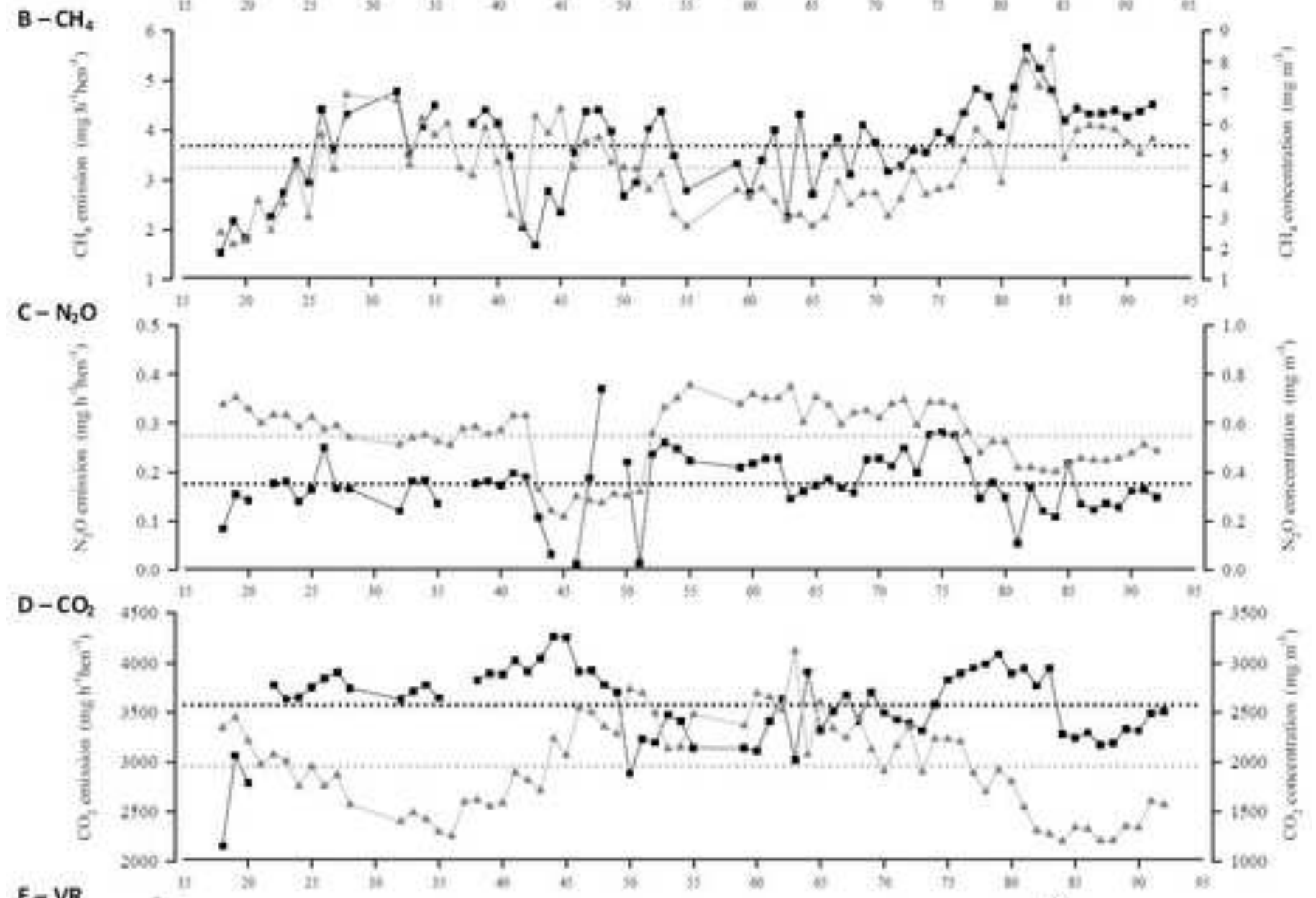

E- VR

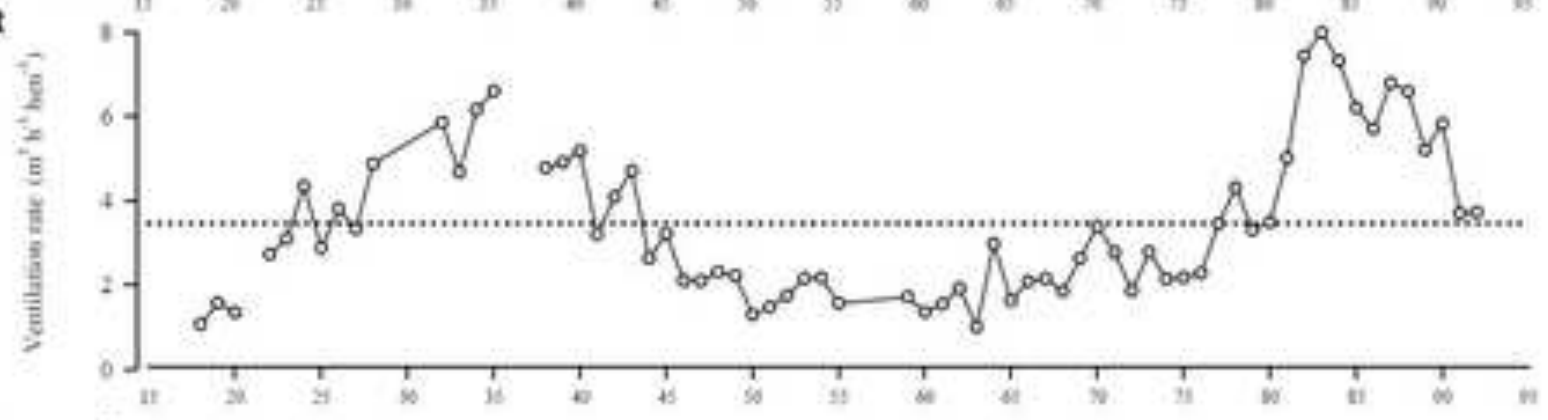

$F-T$

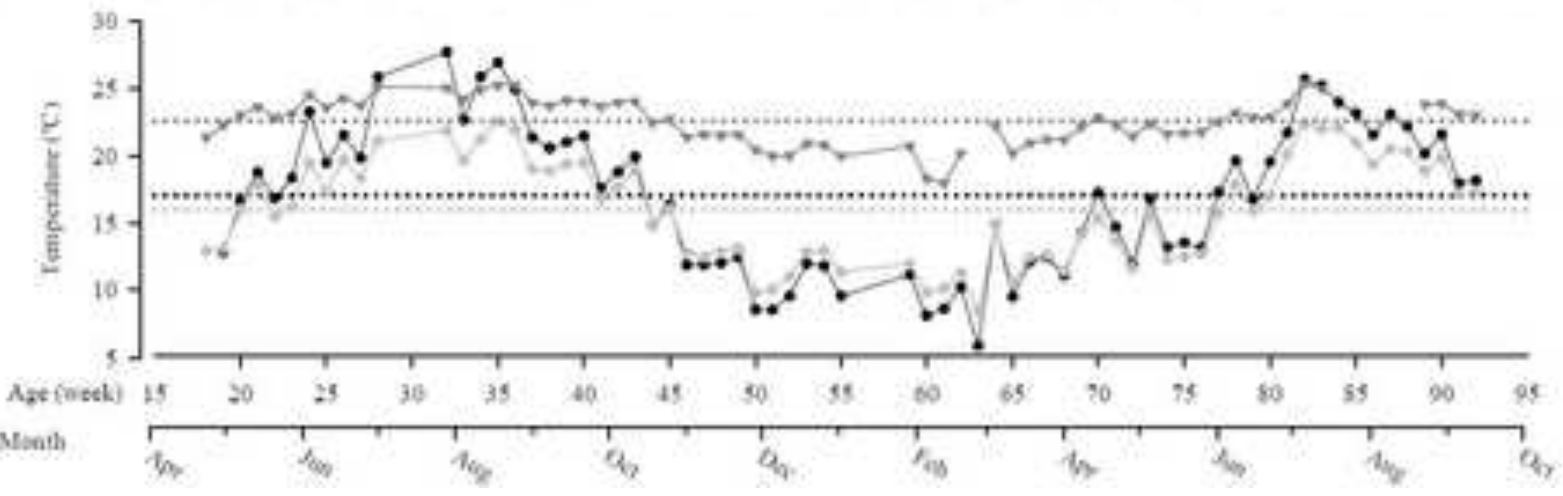



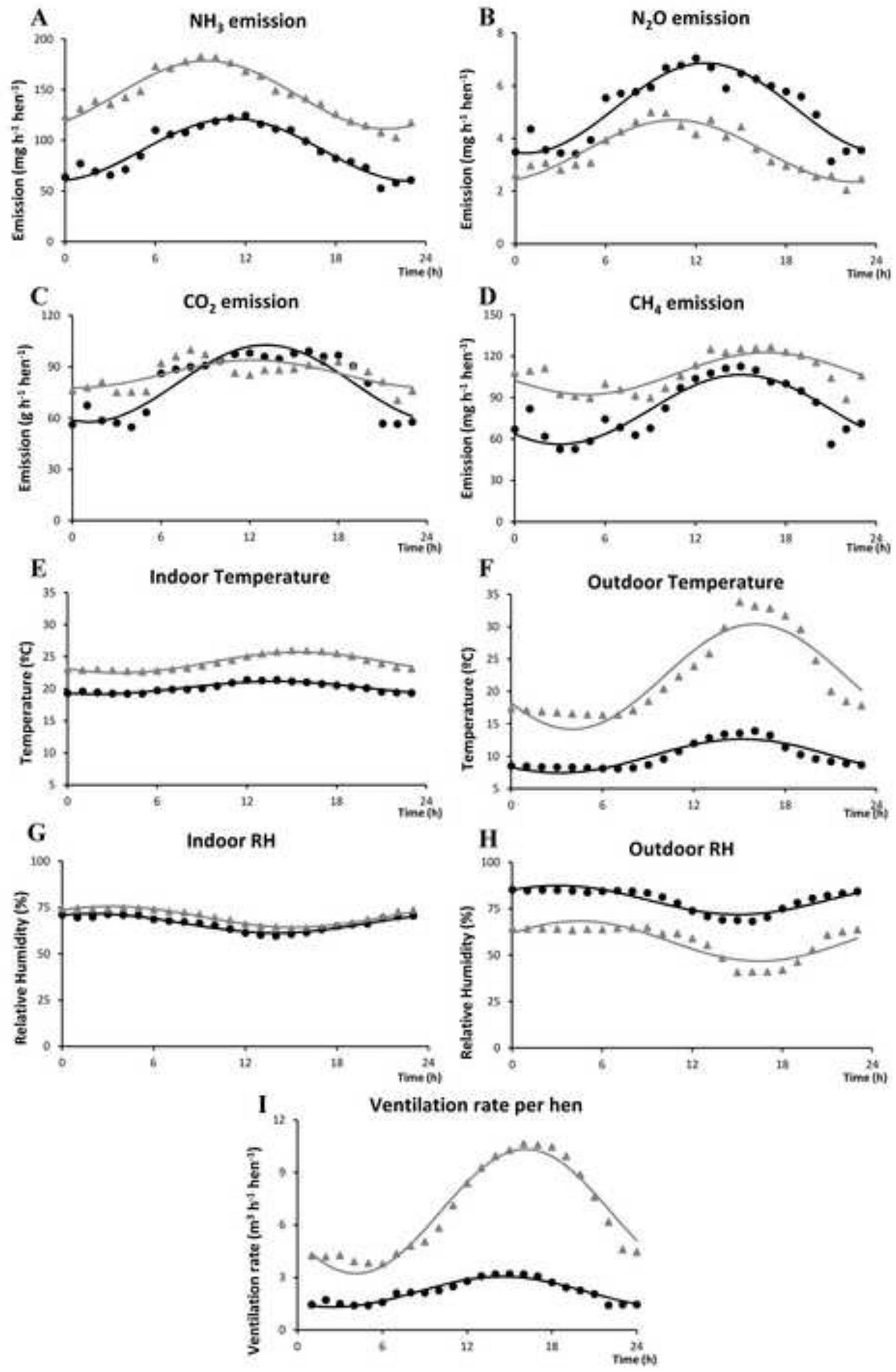
Figure 1. Layout of the house and scheme of the tunnel ventilation system.

Figure 2. Relation of daily ventilation rate $\left(10^{6} \mathrm{~m}^{3} \mathrm{~d}^{-1}\right)$ and outdoor temperature $\left({ }^{\circ} \mathrm{C}\right)$.

Figure 3. Ammonia and GHG emission ( $\boldsymbol{\square}$ ) and concentration ( $\boldsymbol{\Delta}$ ), and ventilation rate (o) per hen and; outlet $(\nabla)$, inlet $(\diamond)$ and outdoor $(\bullet)$ temperature during trial. Dotted lines represent average values.

Figure 4. Average hourly variations in $\mathrm{NH}_{3}, \mathrm{CH}_{4}, \mathrm{~N}_{2} \mathrm{O}$ and $\mathrm{CO}_{2}$ emissions, outdoor and indoor temperature and relative humidity, and ventilation rate for summer $(\boldsymbol{\Delta})$ and winter $(\bullet)$. All modelled curves were significant at $\mathrm{P}<0.001$.

Figure 1. Layout of the house and scheme of the tunnel ventilation system.

Figure 2. Relation of daily ventilation rate $\left(10^{6} \mathrm{~m}^{3} \mathrm{~d}^{-1}\right)$ and outdoor temperature $\left({ }^{\circ} \mathrm{C}\right)$.

Figure 3. Ammonia and GHG emission ( $\mathbf{a})$ and concentration $(\boldsymbol{\Delta})$, and ventilation rate (o) per hen and; outlet $(\nabla)$, inlet $(\diamond)$ and outdoor $(\bullet)$ temperature during trial. Dotted lines represent average values.

Figure 4. Average hourly variations in $\mathrm{NH}_{3}, \mathrm{CH}_{4}, \mathrm{~N}_{2} \mathrm{O}$ and $\mathrm{CO}_{2}$ emissions, outdoor and indoor temperature and relative humidity, and ventilation rate for summer $(\Delta)$ and winter $(\bullet)$. All modelled curves were significant at $\mathrm{P}<0.001$. 
Table 1. Composition of feed for the different feeding phases.

\begin{tabular}{lccc}
\cline { 2 - 4 } & Phase 1 & Phase 2 & Phase 3 \\
\cline { 2 - 4 } & Weeks 18-54 & Weeks 55-74 & Weeks 74-93 \\
\hline Feed Composition & Mean & Mean & Mean \\
\hline Dry Matter (\%) & 89.6 & 89.9 & 90.0 \\
Crude protein (\% DM) & 16.7 & 16.2 & 16.0 \\
Crude fat (\% DM) & 4.2 & 4.4 & 4.1 \\
Crude fiber (\% DM) & 3.8 & 4.0 & 4.7 \\
Organic Matter (\% DM) & 86.5 & 85.1 & 87.3 \\
\hline
\end{tabular}


Table 2. Number of hens, body weight, mortality, percentage of laying, productivity, feed intake and conversion efficiency of laying hens monitored during different feeding phases.

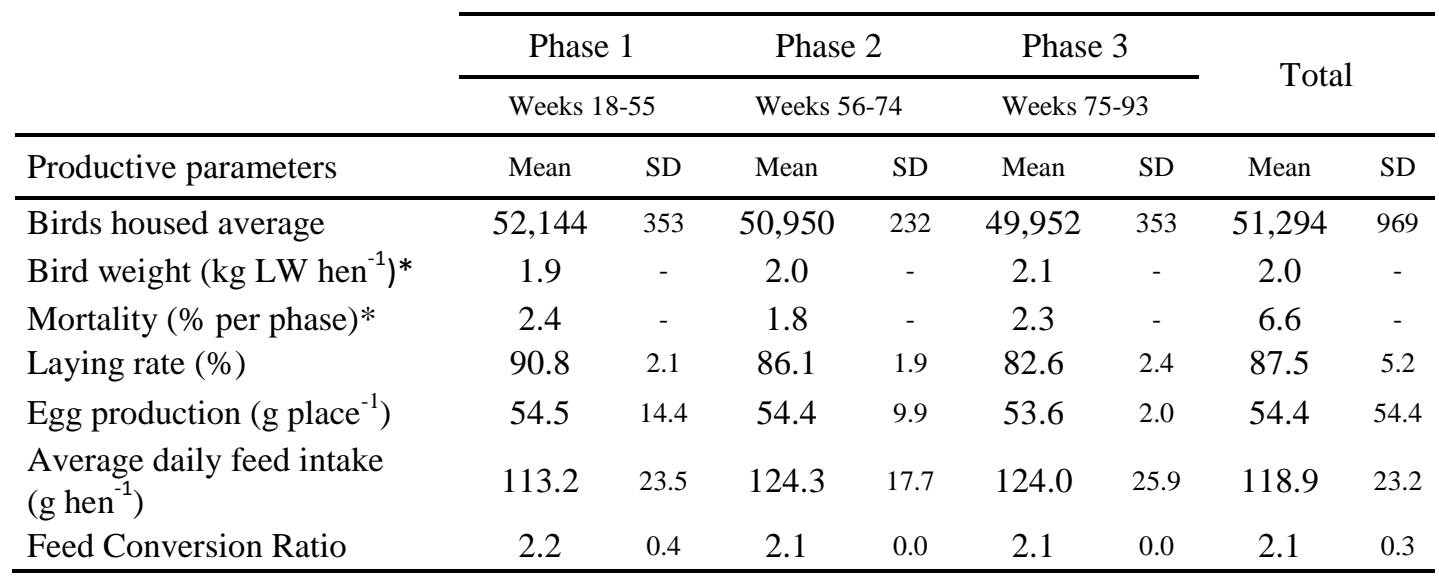

* Average estimated value of the standard deviation 
Table 3. Mean temperature (T) and relative humidity (RH) inside and outside the hen house, ventilation rate (VR), concentrations of GHG and ammonia $\left(\mathrm{NH}_{3}\right)$ outside and inside the hen house, emissions of $\mathrm{GHG}$ and $\mathrm{NH}_{3}$ for each season. Data have been calculated on an hourly basis.

\begin{tabular}{|c|c|c|c|c|c|c|c|c|c|c|c|c|c|c|c|}
\hline \multirow{5}{*}{\multicolumn{2}{|c|}{ Climatic conditions }} & & & & & & & & & & & & & & \\
\hline & & \multicolumn{6}{|c|}{2012} & \multicolumn{6}{|c|}{2013} & & \\
\hline & & \multirow{2}{*}{\multicolumn{2}{|c|}{$\frac{\text { Spring }}{\text { Weeks } 18-27}$}} & \multirow{2}{*}{\multicolumn{2}{|c|}{$\begin{array}{c}\text { Summer } \\
\text { Weeks } 28-40 \\
\end{array}$}} & \multirow{2}{*}{\multicolumn{2}{|c|}{$\begin{array}{c}\text { Autumn } \\
\text { Weeks 41-53 } \\
\end{array}$}} & \multirow{2}{*}{\multicolumn{2}{|c|}{$\begin{array}{c}\text { Winter } \\
\text { Weeks 54-66 } \\
\end{array}$}} & \multirow{2}{*}{\multicolumn{2}{|c|}{$\frac{\text { Spring }}{\text { Weeks 67-79 }}$}} & \multirow{2}{*}{\multicolumn{2}{|c|}{$\begin{array}{c}\text { Summer } \\
\text { Weeks 80-93 }\end{array}$}} & \multirow{2}{*}{\multicolumn{2}{|c|}{ Average }} \\
\hline & & & & & & & & & & & & & & & \\
\hline & & Mean & SD & Mean & SD & Mean & SD & Mean & SD & Mean & SD & Mean & SD & Mean & SD \\
\hline \multirow[t]{2}{*}{$\mathrm{T}\left({ }^{\circ} \mathrm{C}\right)$} & Outside & 16.5 & 4.0 & 20.3 & 3.2 & 15.1 & 3.8 & 11.2 & 2.9 & 13.9 & 3.8 & 19.7 & 3.3 & 15.7 & 4.8 \\
\hline & Inside & 23.2 & 1.6 & 24.5 & 1.8 & 22.5 & 1.6 & 20.1 & 1.8 & 22.0 & 1.3 & 23.8 & 1.6 & 22.4 & 2.1 \\
\hline \multirow[t]{2}{*}{$\mathrm{RH}(\%)$} & Outside & 72.5 & 14.0 & 74.2 & 8.6 & 76.6 & 9.6 & 75.7 & 10.6 & 78.7 & 13.5 & 82.2 & 10.4 & 77.3 & 11.8 \\
\hline & Inside & 62.7 & 7.9 & 68.1 & 7.6 & 64.5 & 7.3 & 66.5 & 11.7 & 64.5 & 7.8 & 71.5 & 6.8 & 66.1 & 8.9 \\
\hline \multicolumn{2}{|c|}{ Ventilation rate $\left(\mathrm{m}^{3} \mathrm{hen}^{-1} \mathrm{~h}^{-1}\right)$} & 3.4 & 2.4 & 6.6 & 3.4 & 3.7 & 2.2 & 2.2 & 1.1 & 3.3 & 2.3 & 6.9 & 3.8 & 4.2 & 3.2 \\
\hline \multicolumn{16}{|l|}{ Concentrations } \\
\hline \multirow[t]{2}{*}{$\mathrm{NH}_{3}\left(\mathrm{mg} / \mathrm{m}^{3}\right)$} & Inlet & 0.8 & 0.2 & 0.6 & 0.1 & 0.5 & 0.1 & 0.4 & 0.2 & 0.4 & 0.1 & 0.3 & 0.1 & 0.5 & 0.2 \\
\hline & Outlet & 2.8 & 1.8 & 1.9 & 1.4 & 2.2 & 1.5 & 2.3 & 1.5 & 1.8 & 1.0 & 1.4 & 0.9 & 2.0 & 1.4 \\
\hline \multirow[t]{2}{*}{$\mathrm{N}_{2} \mathrm{O}\left(\mathrm{mg} / \mathrm{m}^{3}\right)$} & Inlet & 0.6 & 0.0 & 0.5 & 0.0 & 0.4 & 0.1 & 0.6 & 0.1 & 0.5 & 0.1 & 0.4 & 0.0 & 0.5 & 0.1 \\
\hline & Outlet & 0.6 & 0.1 & 0.6 & 0.1 & 0.4 & 0.2 & 0.6 & 0.2 & 0.6 & 0.1 & 0.5 & 0.1 & 0.5 & 0.2 \\
\hline \multirow[t]{2}{*}{$\mathrm{CH}_{4}\left(\mathrm{mg} / \mathrm{m}^{3}\right)$} & Inlet & 2.2 & 1.6 & 4.4 & 2.0 & 4.0 & 1.6 & 2.0 & 0.8 & 2.7 & 1.0 & 5.3 & 1.6 & 3.4 & 1.9 \\
\hline & Outlet & 3.4 & 2.1 & 5.4 & 2.3 & 5.1 & 1.6 & 3.6 & 1.0 & 4.1 & 1.1 & 6.1 & 1.5 & 4.6 & 1.8 \\
\hline \multirow[t]{2}{*}{$\mathrm{CO}_{2}\left(\mathrm{~g} / \mathrm{m}^{3}\right)$} & Inlet & 0.8 & 0.0 & 0.8 & 0.0 & 0.8 & 0.0 & 0.8 & 0.1 & 0.8 & 0.0 & 0.7 & 0.0 & 0.8 & 0.0 \\
\hline & Outlet & 2.0 & 0.5 & 1.5 & 0.4 & 2.2 & 0.5 & 2.5 & 0.5 & 2.1 & 0.4 & 1.4 & 0.3 & 2.0 & 0.6 \\
\hline \multicolumn{16}{|l|}{ Emissions } \\
\hline \multicolumn{2}{|c|}{$\mathrm{NH}_{3}\left(\mathrm{mg} \mathrm{hen}^{-1} \mathrm{~d}^{-1}\right)$} & 118.1 & 85.6 & 165.4 & 129.8 & 119.5 & 77.9 & 90.3 & 68.1 & 98.8 & 68.5 & 136.3 & 86.4 & 115.7 & 85.6 \\
\hline \multicolumn{2}{|c|}{$\mathrm{N}_{2} \mathrm{O}\left(\mathrm{mg} \mathrm{hen}^{-1} \mathrm{~d}^{-1}\right)$} & 3.9 & 2.9 & 4.1 & 2.4 & 4.3 & 2.5 & 5.1 & 2.3 & 5.3 & 3.0 & 3.3 & 2.6 & 4.5 & 2.8 \\
\hline \multicolumn{2}{|c|}{$\mathrm{CH}_{4}\left(\mathrm{mg} \mathrm{hen}{ }^{-1} \mathrm{~d}^{-1}\right)$} & 66.4 & 36.9 & 100.0 & 32.4 & 78.0 & 38.5 & 81.2 & 39.1 & 92.1 & 34.3 & 110.1 & 28.3 & 90.0 & 37.5 \\
\hline \multicolumn{2}{|c|}{$\mathrm{CO}_{2}\left(\mathrm{~g} \mathrm{hen}^{-1} \mathrm{~d}^{-1}\right)$} & 82.3 & 23.0 & 90.5 & 13.5 & 95.9 & 20.6 & 80.2 & 21.9 & 88.1 & 23.2 & 83.9 & 15.4 & 86.4 & 20.9 \\
\hline
\end{tabular}


Table 4. Composition and quantity of belt manure for the different feeding phases

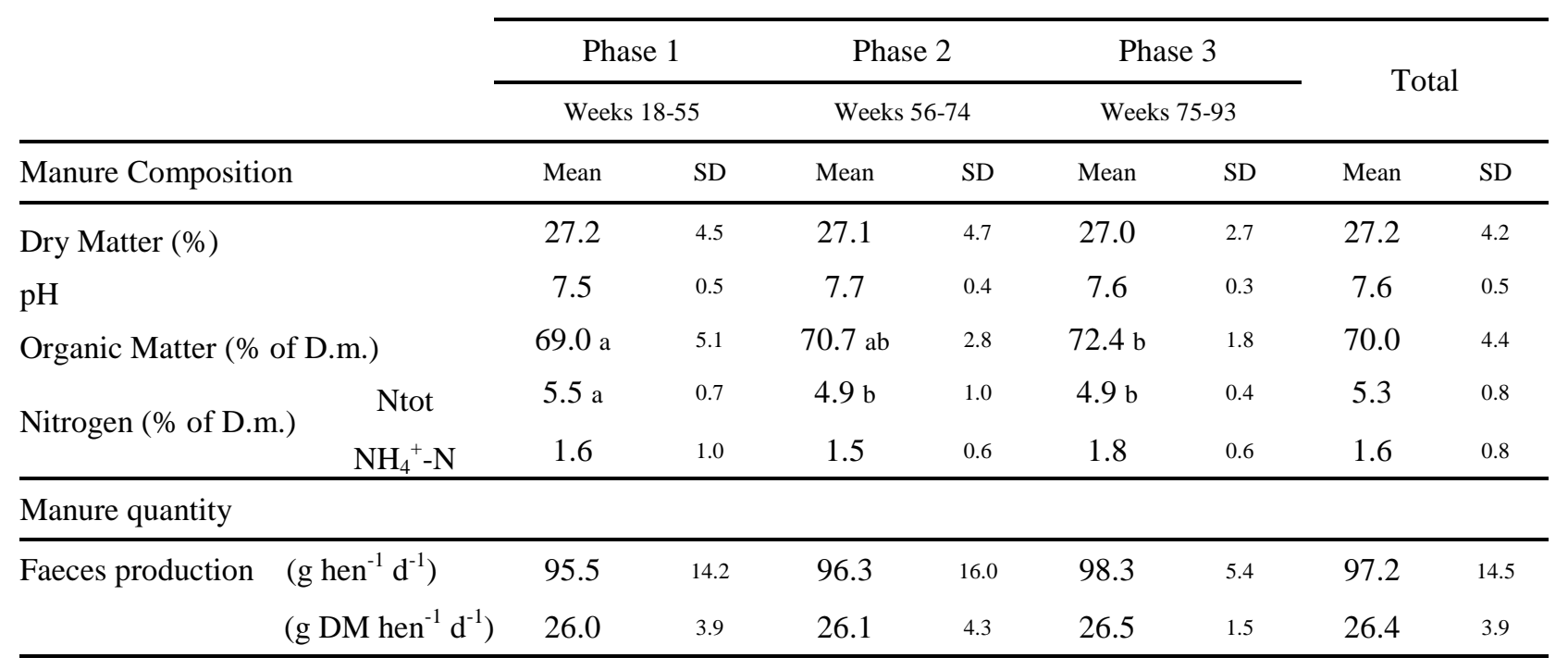

Different superscript letters in the same row indicate statistically significant differences at $\mathrm{P}<0.05$ 
Table 5. Mean values, amplitudes and time at which the maximum occurred $\left(t_{\max }\right)$ in the modelization of diurnal patterns.

\begin{tabular}{lccccccc}
\cline { 3 - 7 } & & \multicolumn{3}{c}{ Summer } & \multicolumn{3}{c}{ Winter } \\
\hline Item & & Mean & Amplitude & $\mathrm{t}_{\text {max }}$ & Mean & Amplitude & $\mathrm{t}_{\text {max }}$ \\
\hline $\mathrm{T}_{\text {out }}$ & $\left({ }^{\circ} \mathrm{C}\right)$ & 22.3 & 8.1 & $16: 09$ & 10.0 & 2.6 & $15: 11$ \\
$\mathrm{~T}_{\text {in }}$ & $\left({ }^{\circ} \mathrm{C}\right)$ & 24.1 & 1.6 & $15: 28$ & 20.1 & 1.0 & $13: 55$ \\
$\mathrm{RH}_{\text {out }}$ & $(\%)$ & 57.5 & 10.8 & $4: 29$ & 79.6 & 7.8 & $3: 42$ \\
$\mathrm{RH}_{\text {in }}$ & $(\%)$ & 70.0 & 5.7 & $3: 13$ & 66.5 & 5.2 & $1: 06$ \\
$\mathrm{VR}$ & $\left(\mathrm{m}^{3} \mathrm{~h}^{-1} \mathrm{hen}^{-1}\right)$ & 6.8 & 3.6 & $15: 08$ & 2.2 & 0.9 & $13: 29$ \\
$\mathrm{NH}_{3}$ & $\left(\mathrm{mg} \mathrm{d}^{-1} \mathrm{hen}^{-1}\right)$ & 144.9 & 33.5 & $9: 25$ & 90.4 & 30.9 & $11: 08$ \\
$\mathrm{CH}_{4}$ & $\left(\mathrm{mg} \mathrm{d}^{-1} \mathrm{hen}^{-1}\right)$ & 107.4 & 15.3 & $16: 45$ & 81.3 & 25.2 & $15: 29$ \\
$\mathrm{~N}_{2} \mathrm{O}$ & $\left(\mathrm{mg} \mathrm{d}^{-1} \mathrm{hen}^{-1}\right)$ & 3.52 & 1.18 & $10: 34$ & 5.15 & 1.71 & $12: 38$ \\
$\mathrm{CO}_{2}$ & $\left(\mathrm{~g} \mathrm{~d}^{-1} \mathrm{hen}^{-1}\right)$ & 85.8 & 8.1 & $12: 12$ & 80.2 & 22.5 & $13: 51$ \\
\hline
\end{tabular}

